\title{
FORTY YEARS OF INCREASING COTTON’S WATER PRODUCTIVITY AND WHY THE TREND WiLl CONTINUE
}

\author{
E. M. Barnes, B. T. Campbell, G. Vellidis, W. M. Porter, J. O. Payero, B. G. Leib, \\ R. Sui, D. K. Fisher, S. Anapalli, P. D. Colaizzi, J. P. Bordovsky, \\ D. O. Porter, S. Ale, J. Mahan, S. Taghvaeian, K. R. Thorp
}

HighLights

- Over the last 40 years the amount of irrigation water used by cotton in the United States has decreased while yields have increased leading to a large increase in crop water productivity (CWP).

- Many factors have contributed to improved CWP, such as improvements in water delivery systems.

- Irrigation scheduling technologies have also contributed to improved CWP; however, farmer adoption of advanced scheduling technologies is still limited and there is significant room for improvement.

- Increased yields from improved cultivars without an increase in water requirements has also been important for CWP.

- Continued developments in sensor technologies and improved crop simulation models are two examples of future strategies that should allow the U.S. cotton industry to continue an upward trend in CWP.

ABSTRACT. Over the last 40 years the amount of irrigation water used by cotton in the United States has decreased while yields have increased. Factors contributing to higher water productivity and decreased irrigation water use include migration of cotton out of the far western U.S. states to the east where more water requirements are met by rainfall; improved irrigation delivery systems with considerable variation in types and adoption rates across the U.S.; improved irrigation scheduling tools; improved genetics and knowledge of cotton physiology, and improved crop models that can help evaluate new irrigation strategies rapidly and inexpensively. The considerable progress over the last 40 years along with the promise of emerging technologies suggest that this progress will continue. (c) $\left(\begin{array}{l}\text { (1) } \\ \text { Th }\end{array}\right.$ The authors have paid for open access for this article. This NonCommercial-NoDerivatives 4.0 International License https://creative commons.org/licenses/by-nc-nd/4.0/

Submitted for review in January 2020 as manuscript number NRES 13911; approved for publication as an Invited Review part of the NIS Collection by the Natural Resources \& Environmental Systems Community of ASABE in April 2020.

Mention of company or trade names is for description only and does not imply endorsement by the USDA. The USDA is an equal opportunity provider and employer.

The authors are Edward M. Barnes, Senior Director, Agricultural and Environmental Research Division, Cotton Incorporated, Cary, North Carolina; B. Todd Campbell, Research Geneticist, USDA-ARS Coastal Plain Soil, Water and Plant Conservation Research, Florence, South Carolina; George Vellidis, Professor, and Wesley M. Porter, Assistant Professor, Crop and Soil Sciences Department, University of Georgia, Tifton, Georgia; Jose O. Payero, Irrigation Specialist, Department of Agricultural Sciences, Clemson University, Blackville, South Carolina; Brian G. Leib, Associate Professor, Biosystems Engineering and Soil Science Department, University of Tennessee, Knoxville, Tennessee; Ruixiu Sui, Research Agricultural Engineer, Daniel K. Fisher, Research Agricultural Engineer, and Saseendran Anapalli, Research Soil Scientist, USDA-ARS Sustainable Water Management Research Unit, Stoneville, Mississippi; Paul D. Colaizzi, Research Agricultural Engineer, USDAARS Conservation and Production Research Laboratory, Bushland, Texas; James P. Bordovsky, Agricultural Engineer, Dana O. Porter, Professor, and Srinivasulu Ale, Associate Professor, Biological and Agricultural Engineering Department, Texas A\&M, College Station, Texas, James Mahan, Research Plant Physiologist, USDA-ARS Cropping Systems Research Laboratory, Lubbock, Texas; Saleh Taghvaeian, Assistant Professor, Biosystems and Agricultural Engineering Department, Oklahoma State University, Stillwater, Oklahoma; and Kelly R. Thorp, Agricultural Engineer, USDA-ARS US Arid-Land Agricultural Research Center, Maricopa, Arizona. Corresponding author: Edward M. Barnes, Cotton Incorporated, 6399 Weston Parkway, Cary, NC 27511; phone: 919678-2368; e-mail: ebarnes@cottoninc.com.

Keywords. Cotton, Crop water productivity, Irrigation, Sustainability, Water use efficiency.

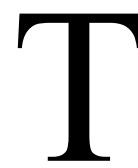
here is little debate that competition for water resources is increasing between agricultural, industrial, metropolitan, and domestic users. Furthermore, there are critical aquifers and river systems that are over allocated and water withdrawals exceed sustainable levels. Therefore, the need to optimize, and reduce where possible, agricultural water use will continue into the foreseeable future. Competing demands for water resources have occurred since irrigation became common practice in regions of the United States (U.S.) resulting in a long history of agricultural water management research.

One key focus of water management research over the last forty years has been to increase cotton's water productivity. The term "crop water productivity" (CWP) is defined as the ratio of the crop yield with economic value to seasonal evapotranspiration, as shown in equation 1 :

$$
C W P=Y(E T)^{-1}
$$

where

$\mathrm{Y}=$ yield $\left(\mathrm{kg} \mathrm{ha}^{-1}\right)$, and

$\mathrm{ET}=$ evapotranspiration used in producing $\mathrm{Y}\left(\mathrm{m}^{3} \mathrm{ha}^{-1}\right)$. 
For cotton, both the fiber and seed are of economic value; however, in many cases only fiber yield is reported when considering CWP and that convention will be followed in this paper. The CWP term is a common metric for comparing crop production subject to different conditions (e.g., irrigation rates, genetic varieties, climate, seasons, etc.) and combines three possible water sources (i.e., irrigation, precipitation, soil water depletion) to a single metric (Bos, 1980; Howell, 2001). Thus CWP applies to both irrigated and non-irrigated crop production. Irrigation crop water productivity (ICWP) can be defined as:

$$
I C W P=\left(Y_{i}-Y_{d}\right) I R^{-1}
$$

where

$\mathrm{Y}_{\mathrm{i}}=$ irrigated yield $\left(\mathrm{kg} \mathrm{ha}^{-1}\right)$,

$\mathrm{Y}_{\mathrm{d}}=$ non-irrigated yield $\left(\mathrm{kg} \mathrm{ha}^{-1}\right)$, and

$\mathrm{IR}=$ irrigation water applied $\left(\mathrm{m}^{3} \mathrm{ha}^{-1}\right)$.

The ICWP term is a measure of yield gained due to irrigation that otherwise would not have been attained in a nonirrigated production system, and has been an important metric for examining the role of irrigation, separate from precipitation or soil water extraction, in irrigated crop production studies (Bos, 1980). CWP and ICWP have units of mass per volume of water (e.g., $\mathrm{kg} \mathrm{m}^{-3}$ ). Therefore, they are not true efficiency terms because they are not unitless (Howell, 2001, Howell and Lamm, 2007), and for this reason, CWP is gaining ground in replacing the term "water use efficiency" (e.g., Zwart and Bastiaanssen, 2004). Data required to calculate CWP and ICWP have been documented in many crop production studies, including cotton, so that factors that influence the conversion of water to biomass are readily compared and elucidated.

U.S. cotton growers have an established history of increasing crop water productivity as evidenced by yield increasing (USDA-NASS Quick Stats, accessed September $25,2019)$ and irrigation water used for cotton decreasing (USDC (1984, 1990); USDA-NASS (1994,1999, 2004, 2010, 2014, 2019)) as illustrated in figure 1.

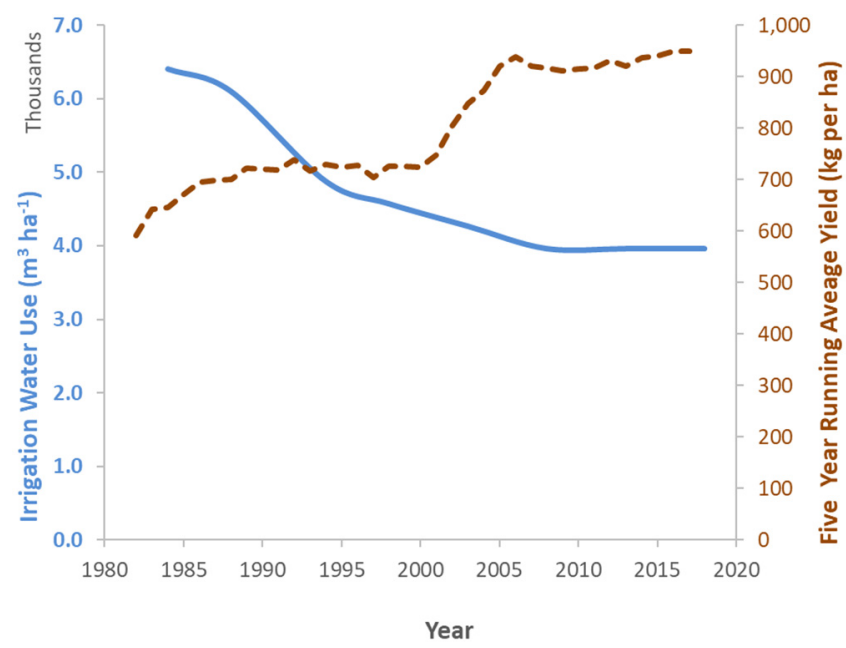

Figure 1. U.S. average cotton yield (USDA-NASS, QuickStats, accessed September 25, 2019, five-year running average from 1980 to 2019) and average annual irrigation water use by cotton [USDC (1984; 1990); USDA-NASS (1994, 1999, 2004, 2010, 2014, 2019)].
Part of the decline in U.S. irrigation water use can be attributed to a migration of cotton from the far western states (California and Arizona) to areas eastward where rainfall meets more of the crop water demand, due to water costs in the west, and the successful eradication of the boll weevil in the east (figs. 2 and 3). However, that is not the only factor resulting in increased CWP. California and Arizona remain the highest yielding states of the U.S. Cotton Belt and average U.S. yields still increased as the cotton area moved to less productive regions while irrigation water used continued to decline. The four cotton growing regions in the U.S. will be defined as:

1. Far West (FW): California, Arizona, New Mexico

2. Southwest (SW): Texas, Oklahoma, Kansas

3. Midsouth (MS): Missouri, Arkansas, Mississippi, Tennessee, Louisiana

4. Southeast (SE): Alabama, Virginia, North Carolina, South Carolina, Georgia, Florida

The objectives of this article were to examine how: 1 ) improved water delivery systems; 2 ) better irrigation scheduling technologies; and 3) other agronomic factors have contributed to the increase in the CWP of U.S. cotton. The final objective was to review what technological innovations are needed to continue improving cotton's CWP.

\section{AdVANCes IN Water Delivery SYSTEMS}

A significant factor contributing to U.S. cotton's increased CWP has been improved water delivery systems, including the conversion or replacement from gravity-based (furrow and basin) to sprinkler and microirrigation systems (fig. 4). The adoption of new delivery systems has a strong regional component (table 1), so this section looks at trends in irrigation system changes over the last 40 years in terms of the four cotton production regions in the U.S. (FW, SW, MS, SE; fig. 3). Pressurized irrigation systems, such as center pivot, lateral move, and microirrigation, often increase application efficiency, energy efficiency, and nutrient use efficiency compared with surface (gravity flow) irrigation systems. Pressurized systems are well suited to automation, and thus improve management options both spatially and temporally. They offer flexibility to apply water in relatively small amounts (depths) with relatively flexible timing. Fertigation and other chemigation technologies allow the user greater flexibility, improving crop response to water, nutrients, and agrichemicals.

\section{FAR WEST (FW)}

Cotton production has declined steadily in the Far West U.S. due to declining water resources and competition from more valuable crops such as almonds and processing tomatoes in California (Geisseler and Horwath, 2016). Essentially, all Far West cotton production requires irrigation due to the arid climate Most of the cotton growing area in the region receives water through canal systems and that has a significant impact on water delivery methods. Surface irrigation (both furrow through siphon tubes and level basin) 


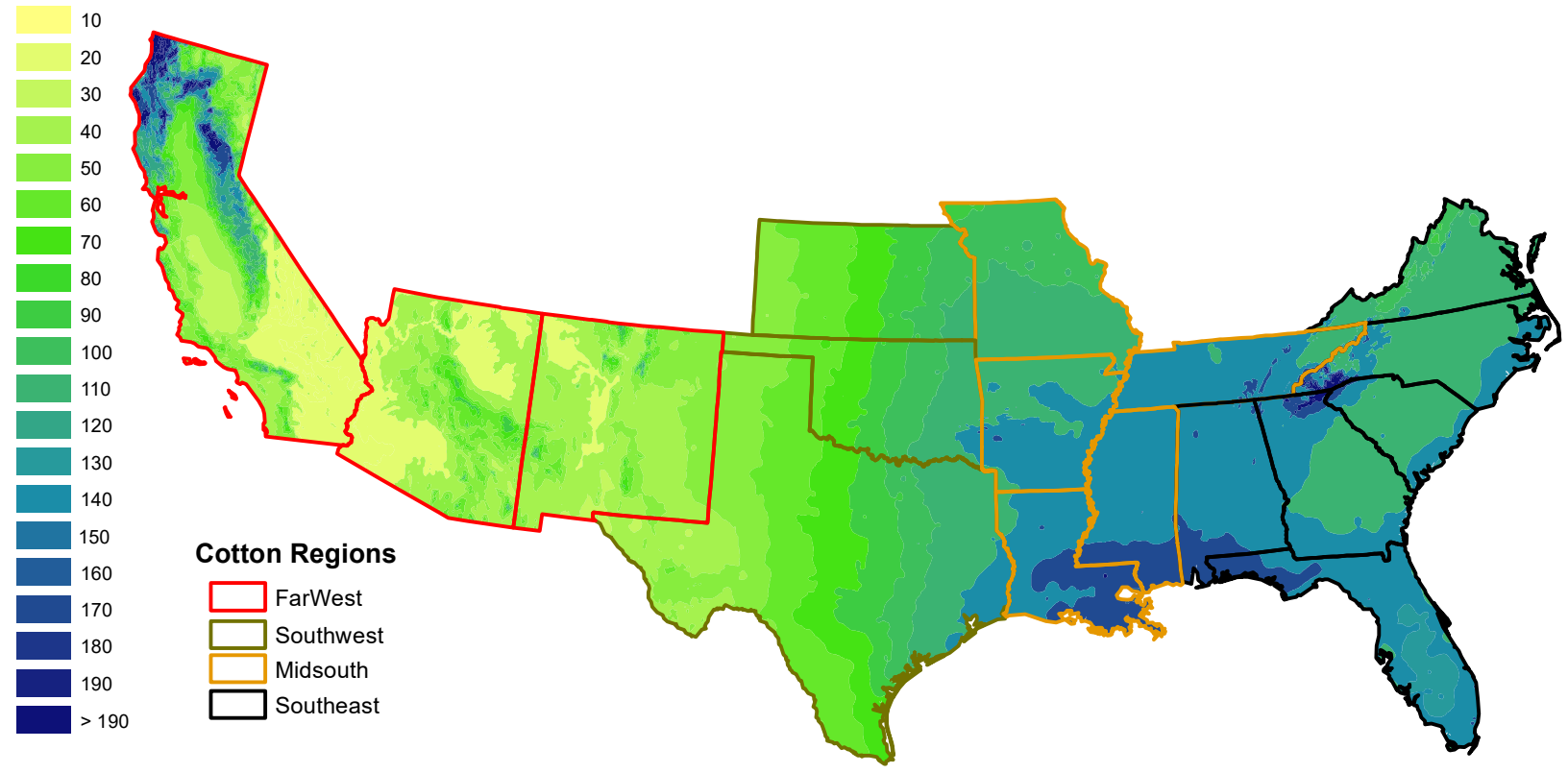

Figure 2. U.S. cotton growing states and regions overlaying 30-year average rainfall from 1971-2000 (USDA-NRCS, 2012a).

remains the most common irrigation method (table 1), supported by heavy tillage practices and cotton planting on raised beds between irrigation furrows. This production system remains popular because of existing infrastructure for delivery of Colorado River water to growers through irrigation district canals. Early efforts to improve irrigation management for these systems sought to optimize timings for the first post-plant irrigation event (Steger et al., 1998) and the final irrigation event of the season (Unruh and Silvertooth, 1997; Tronstad et al., 2003). Both Radin et al. (1992) and Hunsaker et al. (1998) reported higher cotton yield and water productivity by applying smaller amounts of surface irrigation more frequently.

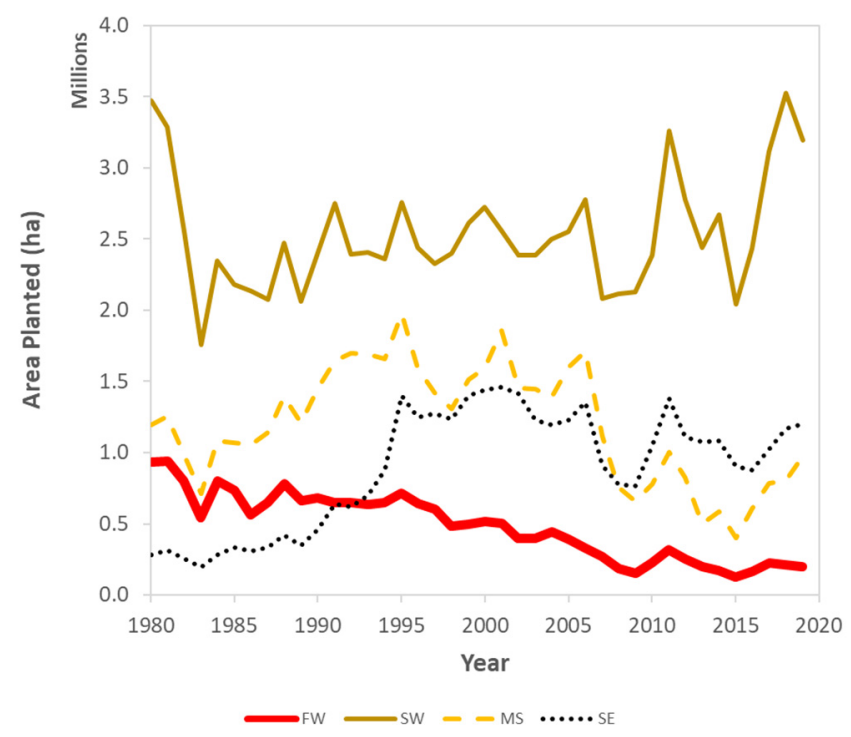

Figure 3. Trends in U.S. cotton planted area by region from 1980 to 2019 (USDA-NASS Quickstats, accessed 24 October 2019).
Smith et al. (2005) found irrigation application efficiencies ranged from $17 \%$ to $100 \%$ in surface irrigated cotton fields in Australia, where the efficiency differences were largely attributed to management and design of the surface systems. Soil type also has a significant impact on efficiency that can be achieved with surface irrigation, where deeper and greater water holding capacity soils are better suited to surface irrigation systems (Negri and Brooks, 1990). Improvements in the design of surface irrigation systems have been facilitated by the wide availability of precision grading systems to precisely control the slope in surface irrigated cotton fields of the Far West cotton growing region (Frisvold et al., 2018). Other key factors in improving the application efficiency of surface irrigation in the Far West has been better water flow measurements in farm level canals and the use of large flow inlets for basin irrigation systems. Computeraided design and the ability to use feedback control of water inflow rates has also contributed to better application efficiency for surface irrigated systems (Clemmens, 1992; Bautista et al., 2009).

\section{SOUTHWEST (SW)}

The Southwest U.S. consistently contains the greatest area planted to cotton in the United States, with Texas having the largest area in 2018 (table 1). Low pressure center pivot sprinkler irrigation systems dominate much of the Southern High Plains. Low Energy Precision Application (LEPA) was developed in the Texas High Plains approximately 40 years ago (Bordovsky, 2019), and together with variations on the technology, are used on over $75 \%$ of the irrigated area in the region (Amosson et al., 2015). In 1978, the LEPA irrigation concept was inspired and developed out of the need to address two critical issues: the impending depletion of available irrigation water from the Ogallala Aquifer (McGuire, 2017) and the quadrupling of natural gas 
Percent of Irrigated Cotton Area by Irrigation System

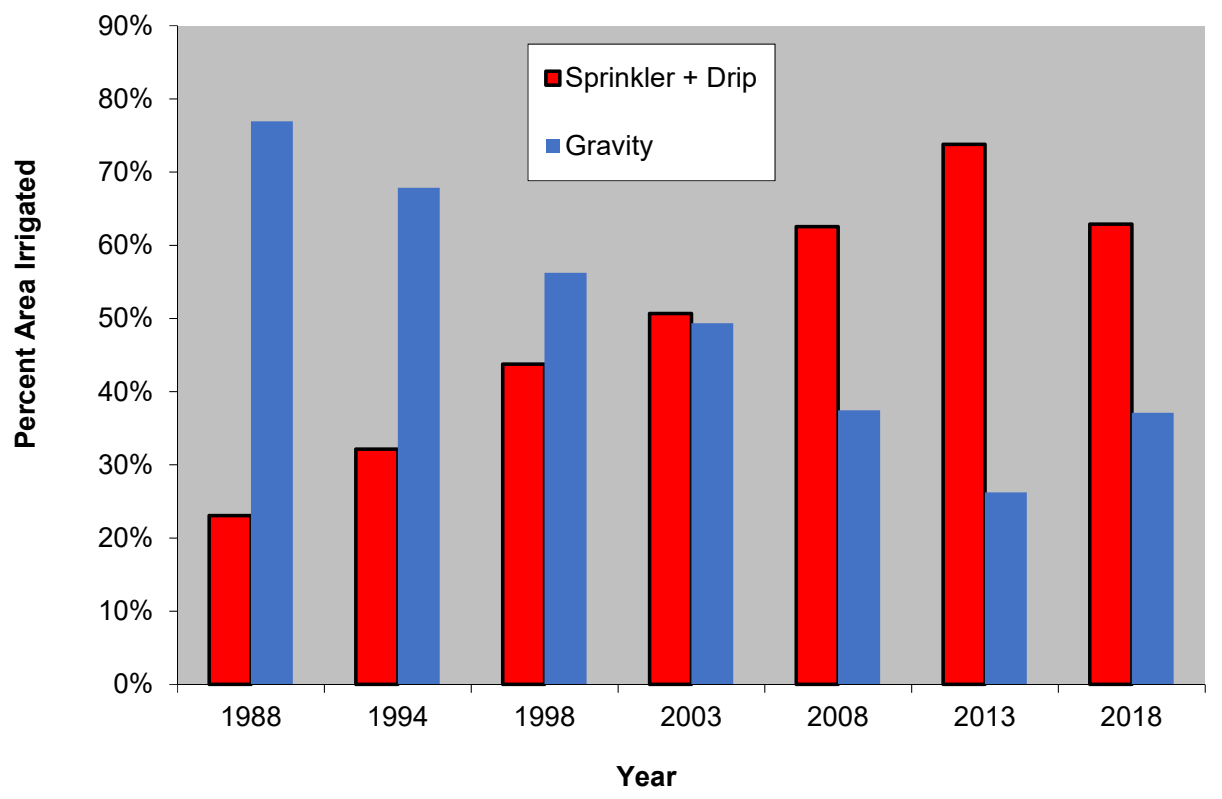

Figure 4. Percent of cotton area under pressurized and gravity-based irrigation systems - data from USDC (1984, 1990) and USDA-NASS (1994, 1999, 2004, 2010, 2014, 2019).

Table 1. Harvested area, percent irrigated, and percent of irrigation system type in 2018 for cotton by state (USDA-NASS, 2019).

\begin{tabular}{|c|c|c|c|c|}
\hline $\begin{array}{l}\text { State } \\
\text { or } \\
\text { Region }\end{array}$ & $\begin{array}{c}\text { Harvested } \\
\text { Area } \\
\text { (ha) }\end{array}$ & $\begin{array}{l}\text { Percent of } \\
\text { Harvested } \\
\text { Area } \\
\text { Irrigated }\end{array}$ & $\begin{array}{l}\text { Percent } \\
\text { Sprinkler } \\
\text { Irrigation }^{[a]}\end{array}$ & $\begin{array}{c}\text { Percent } \\
\text { Surface } \\
\text { (Gravity) } \\
\text { Irrigation }\end{array}$ \\
\hline Arizona & 70,243 & $100 \%$ & na & $95 \%$ \\
\hline California & 104,049 & $99 \%$ & na & $92 \%$ \\
\hline New_Mexico & 25,425 & $82 \%$ & $50 \%$ & $50 \%$ \\
\hline Total FW ${ }^{[b]}$ & 199,717 & $97 \%$ & $7 \%$ & $89 \%$ \\
\hline Kansas & 61,538 & $27 \%$ & $100 \%$ & $0 \%$ \\
\hline Oklahoma & 222,672 & $21 \%$ & $57 \%$ & $43 \%$ \\
\hline Texas & $1,768,219$ & $37 \%$ & $83 \%$ & na \\
\hline Total SW ${ }^{[\mathrm{b}]}$ & $2,052,429$ & $35 \%$ & $81 \%$ & $5 \%$ \\
\hline Arkansas & 194,332 & $80 \%$ & $11 \%$ & $89 \%$ \\
\hline Louisiana & 76,518 & $18 \%$ & na & na \\
\hline Mississippi & 248,988 & $34 \%$ & $39 \%$ & $61 \%$ \\
\hline Missouri & 130,364 & $65 \%$ & $9 \%$ & $91 \%$ \\
\hline Tennessee & 143,725 & $7 \%$ & na & na \\
\hline Total MS & 793,927 & $44 \%$ & $18 \%$ & $82 \%$ \\
\hline Alabama & 201,215 & $11 \%$ & $89 \%$ & $11 \%$ \\
\hline Florida & 37,652 & $0 \%$ & na & na \\
\hline Georgia & 528,340 & $36 \%$ & $100 \%$ & $0 \%$ \\
\hline North Carolina & 168,016 & $3 \%$ & $100 \%$ & $0 \%$ \\
\hline South Carolina & 111,336 & $14 \%$ & $100 \%$ & $0 \%$ \\
\hline$\underline{\text { Virginia }}$ & 39,271 & $0 \%$ & $100 \%$ & $0 \%$ \\
\hline Total SE & $1,085,830$ & $21 \%$ & $99 \%$ & $1 \%$ \\
\hline United States $^{[b]}$ & $4,131,903$ & $36 \%$ & $60 \%$ & $37 \%$ \\
\hline $\begin{array}{l}\text { [a] "na" - either } \\
\text { [b] FW and SW } \\
\text { shown in the } \\
\text { microirrigati }\end{array}$ & $\begin{array}{l}\text { not availab } \\
\text { ons do not s } \\
\text { e and those }\end{array}$ & $\begin{array}{l}\text { too sma } \\
\text { o } 100 \% \\
\text { regions }\end{array}$ & $\begin{array}{l}\text { ample size } \\
\text { icroirrigatio } \\
\text { ve cotton p }\end{array}$ & $\begin{array}{l}\text { report. } \\
\text { is not } \\
\text { duced with }\end{array}$ \\
\hline
\end{tabular}

prices in the mid-1970s (EIA, 2018). At the time, lighter textured soils were irrigated by high-pressure "hand-moved" and some center pivot systems; however, surface (furrow) irrigation was the predominant method of irrigation in the southwest U.S. Rather than spraying water into the air at moderate to high pressures, the LEPA method used a tower/ truss system to apply water directly to a fraction of the soil surface at low pressure using a system that continually moved through the field, requiring one of several complementary cultural practices (e.g., furrow dikes; Schneider and Howell, 2000) to store applied water until infiltration occurred. A properly managed LEPA system reduced many of the regional negative effects of surface and sprinkler systems, such as runoff, excessive evaporation, and high water distribution pressure while increasing irrigation productivity by up to $30 \%$ over gravity methods and sprinkler methods (Lyle and Bordovsky, 1983; Bordovsky, 2019).

Because the LEPA system was developed as an irrigation management concept that required furrow dikes, circular center pivot rows, and minimal slopes, derivatives of the LEPA method were developed to allow more flexibility while addressing typical water losses. These systems included LESA (low elevation spray application), LPIC (low pressure in-canopy), and MESA (mid-elevation spray application) (Lamm et al., 2019). In the southwest U.S, LESA and LPIC have become the most commonly used systems for cotton irrigation (Colaizzi et al., 2009), and they are illustrated in figure 5 . 


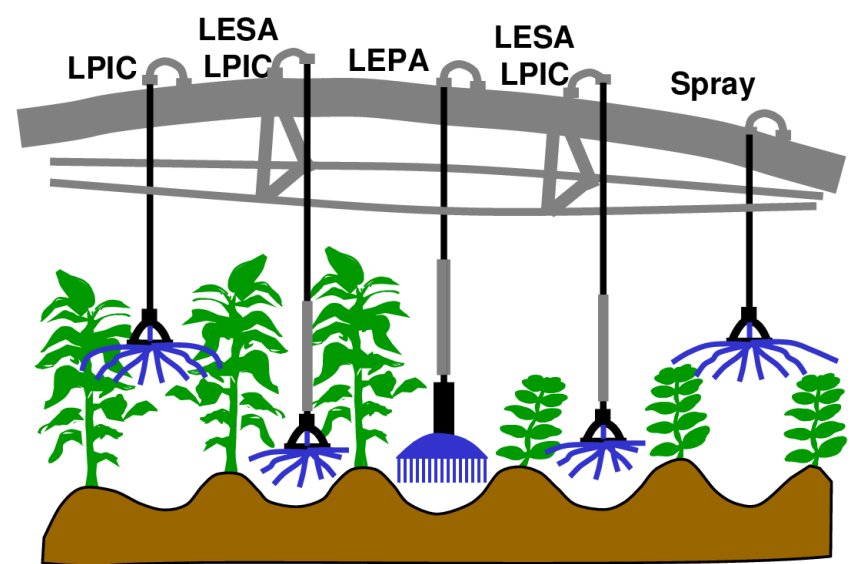

Figure 5. Illustration of the low energy precision application (LEPA), low elevation spray application (LESA), low pressure in-canopy (LPIC), and spray application concepts in tall and short crops (from Howell, 2006).

The prevalence of sprinklers in the SW (more than $80 \%$ of the irrigated area, table 1) make it a prime region for potential adoption of variable rate irrigation (VRI) as suggested by O'Shaughnessy et al. (2013). Despite this potential, and despite VRI hardware being commercially available since 2004, adoption has been low due to several factors as reviewed by O'Shaughnessy et al. (2019). One gap identified as inhibiting adoption is lack of commercially available decision support tools needed to manage VRI, but these are being rapidly developed. One such effort is an Irrigation Scheduling and Supervisory Control And Data Acquisition (ISSCADA) system (Evett et al., 2014). The system is suitable for both moving (e.g., center pivot) and non-moving (microirrigation) systems, but most development has focused on center pivot applications, including generating prescription maps for cotton (O'Shaughnessy et al., 2015).

The continued declines in available water and documented greater application efficiencies of subsurface drip irrigation (SDI) have resulted in a rapid adoption rate of it for cotton production in Texas, Oklahoma, and New Mexico. Adoption of SDI has increased greatly in recent years, from an estimated 8,000 to 10,000 ha in 2000 to over 180,000 ha in 2019 in the Texas High Plains alone (HPWD, 2019). The rapid adoption has occurred despite several issues, including greater initial costs, poor germination during drought conditions, and the need for rodent control (Lamm, 2009; Lamm et al., 2012). Solutions to these issues would likely further increase the adoption of SDI. This rapid growth is attributed to several factors, including limited and declining irrigation well capacities, government cost-share programs, availability of experienced irrigation dealers and designers, a critical mass of progressive cotton producers, and collaboration among and between irrigation research and extension programs, the irrigation industry, and crop producers. An extensive review of cotton research with SDI was presented by Lamm (2016).

Studies in Texas have shown that SDI can result in 15\% to $30 \%$ greater cotton yield, along with better fiber quality, greater CWP, and in some cases, less seasonal water use, compared with MESA, LESA, and LEPA (Bordovsky and
Lyle, 1998; Bordovsky, 2001; Colaizzi et al., 2010; Bordovsky, 2019). Based on results from pairs of large weighing lysimeters at Bushland, Texas, water losses due to evaporation were reduced by 50 to $125 \mathrm{~mm}$ using SDI compared to sprinkler irrigation (Evett et al., 2019). An additional factor important for cotton production is that SDI maintains warmer soil temperatures near the surface compared with sprinkler applicators (Colaizzi et al., 2010). This is due to reduced evaporative cooling for SDI, which applies water below the soil surface, compared with methods where water is applied to the surface. This is critical for cotton establishment early in the season, especially when air and soil temperatures are below optimal for cotton growth. Although this is not a great concern in the traditional cotton producing regions with abundant heat units, it is a primary constraint, in addition to water, for thermally limited climates (e.g., northwest Texas and Kansas) as discussed by Colaizzi et al. (2009).

The concept of mobile drip irrigation (MDI) appears to have originated with Rawlins et al. (1974) and was later described in Howell and Phene (1983) and Phene et al. (1985). An MDI system was recently commercialized as a retrofit to existing center pivot and lateral move irrigation systems. The MDI system applies water through specially designed surface driplines that are pulled through fields by the irrigation machine (Kisekka et al., 2017; O'Shaughnessy and Colaizzi, 2017). Similar to the LEPA method, which applies water on the soil surface between crop rows, MDI reduces water losses due to spray evaporation, evaporation from a wetted canopy, and wind drift resulting in increased efficiency. One advantage MDI may have over LEPA or LESA is its potential use on topography of greater slope without using furrow dikes, due to its extended wetting pattern. Studies in Texas and Kansas have shown that MDI results in improved CWP compared with LEPA or LESA for corn in years with average to below average precipitation, but not for years with above average precipitation (Kisekka et al., 2017; O'Shaughnessy and Colaizzi, 2017). Additional studies are clearly needed to test MDI vs. LEPA or LESA for cotton, particularly in drought conditions.

\section{MIDSOUTH (MS)}

The Midsouth is a highly productive agricultural area dominated by the Mississippi Delta region, which extends into most of the states. Most of the Delta consists of deep alluvial soils, high annual precipitation, and long, frost-free cropping seasons (Snipes et al., 2005). While annual rainfall is abundant, the majority falls outside of the growing season and is highly variable from year to year. This variability results in the need for irrigation to meet crop water requirements to maintain yields and profitability, but not on a consistent year-to-year basis. In some years, rainfall patterns are such that no irrigation is needed, making it difficult for producers to prepare seasonal irrigation strategies in advance.

Irrigation in the Midsouth is accomplished predominantly via gravity flow (furrow) and center pivot methods (Kebede et al., 2014). Furrow irrigation accounts for $70 \%$ to $80 \%$ of the irrigated area, with the remaining area serviced by center pivot systems (table 1). Water is commonly supplied by on- 
farm wells and pumped from the shallow Mississippi River Valley Alluvial Aquifer. Furrow irrigation in this region typically consists of delivering water to the field using roll-flat polyethylene tubing (polypipe), with holes punched in the polypipe to deliver water to each furrow. The technology is simple, inexpensive, and easy to manage, and the preferred option when irrigations may be infrequent and supplementary rather than always a part of annual production operations.

Furrow irrigation application efficiencies are often low, resulting from nonuniform distribution of water across the field and down the furrows. Excessive water applied at the top of field near the polypipe results in saturated soils and deep percolation losses. Irrigation is often terminated when water reaches the bottom end of the furrows, to minimize runoff and wasting of water, resulting in insufficient application at the bottom part of the field. Various tools and methods employed in other regions have been demonstrated and promoted to increase the efficiency of furrow irrigations. Massey (2010) and Ray (2013) have demonstrated how the efficiency of furrow irrigation can be improved, especially for irregularly shaped or sloped fields, using computerizedhole selection software such as Pipe Hole and the Universal Crown Evaluation Tool (PHAUCET, USDA-NRCS, 2012b), or Pipe Planner (Delta Plastics, 2019). Researchers in Arkansas, Mississippi, and Louisiana reported savings of approximately $20 \%$ in water, fuel, and irrigation water using computerized-hole selection in regular-shaped fields, and savings of water as much as $50 \%$ in irregular-shaped fields (Massey, 2011; Ray, 2013; Krutz, 2013).

Furrow irrigation efficiencies in the Midsouth can also potentially be improved using surge-flow valves (Krutz, 2013). In conventional furrow irrigation, water is applied continuously at a constant rate throughout the entire irrigation cycle, overirrigating part of the field while underirrigating other parts. Surge-flow valves regulate the application of water by intermittent and variable (pulsed) application, which modifies soil infiltration characteristics to distribute water more uniformly across the field and reduces water losses by deep percolation and runoff.

An opportunity for improvement in the MS is increased use of flow measurement devices to more precisely monitor irrigation water use. Daystar et al. (2017) found that only about $59 \%$ of cotton producers reported using such devices, as they often assume the original design flow remains constant. McDougall et al. (2014) monitored irrigation wells in central and eastern Arkansas and found pumping rates often did not match the original tests, and there was seasonal fluctuation in flow rates due to changes in water table depth.

Due to the abundant rainfall in the MS, farm ponds are commonly used to store rainfall runoff in the region. There are now studies to see if shallow groundwater recharge can be accomplished with "leaky" farm ponds and reservoirs (Yaeger et al., 2017). On-farm storage of rainfall runoff for subsequent irrigation will be even more critical in the future if climate models predicting more intense and less frequent rainfall events are accurate.

\section{SOUTHEAST (SE)}

Center pivot irrigation is the predominant type of irrigation utilized for row crop production in the southeast (table 1). Like the Southwest, VRI for pivots has been evaluated in the SE (Perry et al., 2002; Perry and Pocknee, 2003) (fig. 6). VRI is now widely commercialized and offered by most of the world's center pivot manufacturers, and VRI can be installed retroactively on most existing pivots. Application amounts are determined from a prescription map. For the system developed at the University of Georgia, each group of sprinklers represents a grid with a $1^{\circ}$ to $10^{\circ}$ arc in which the irrigation water application amount can be set as a percentage of the normal application amount rate ranging from $0 \%$ to $200 \%$ of normal (fig. 7 ).

The prescription map for water application is usually developed jointly by the farmer and VRI dealer on desktop software and then downloaded to the VRI control panel on the pivot. The field is divided into irrigation management zones (IMZs), and application rates are assigned to each of the IMZs using whatever information is available. Although VRI is a great leap forward in improving water use efficiency, the system could be greatly enhanced by having realtime information on crop water needs to drive irrigation application rates. One approach for creating dynamic prescription maps is to use soil water sensors to estimate the amount of irrigation water needed in each IMZ.

VRI adoption is still limited in the southeast due to cost of technology, reliability of technology, management time required for the technology, the needed clarification on how to develop the VRI maps, the lack of easily recognizable return on investment of the technology, and the greater need for intense management (O'Shaughnessy et al., 2019). The irrigation companies that offer VRI are considering dynamic VRI solutions but the cost and the other problems associated

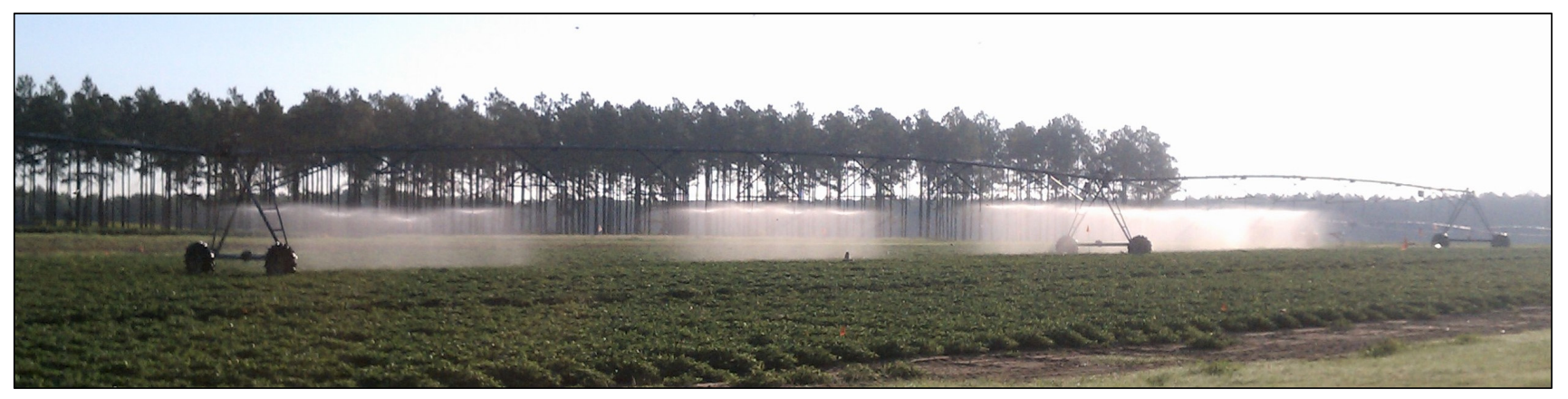

Figure 6. Variable rate irrigation enabled pivot at the University of Georgia's Stripling Irrigation Research Park applying different irrigation rates over research plots. 


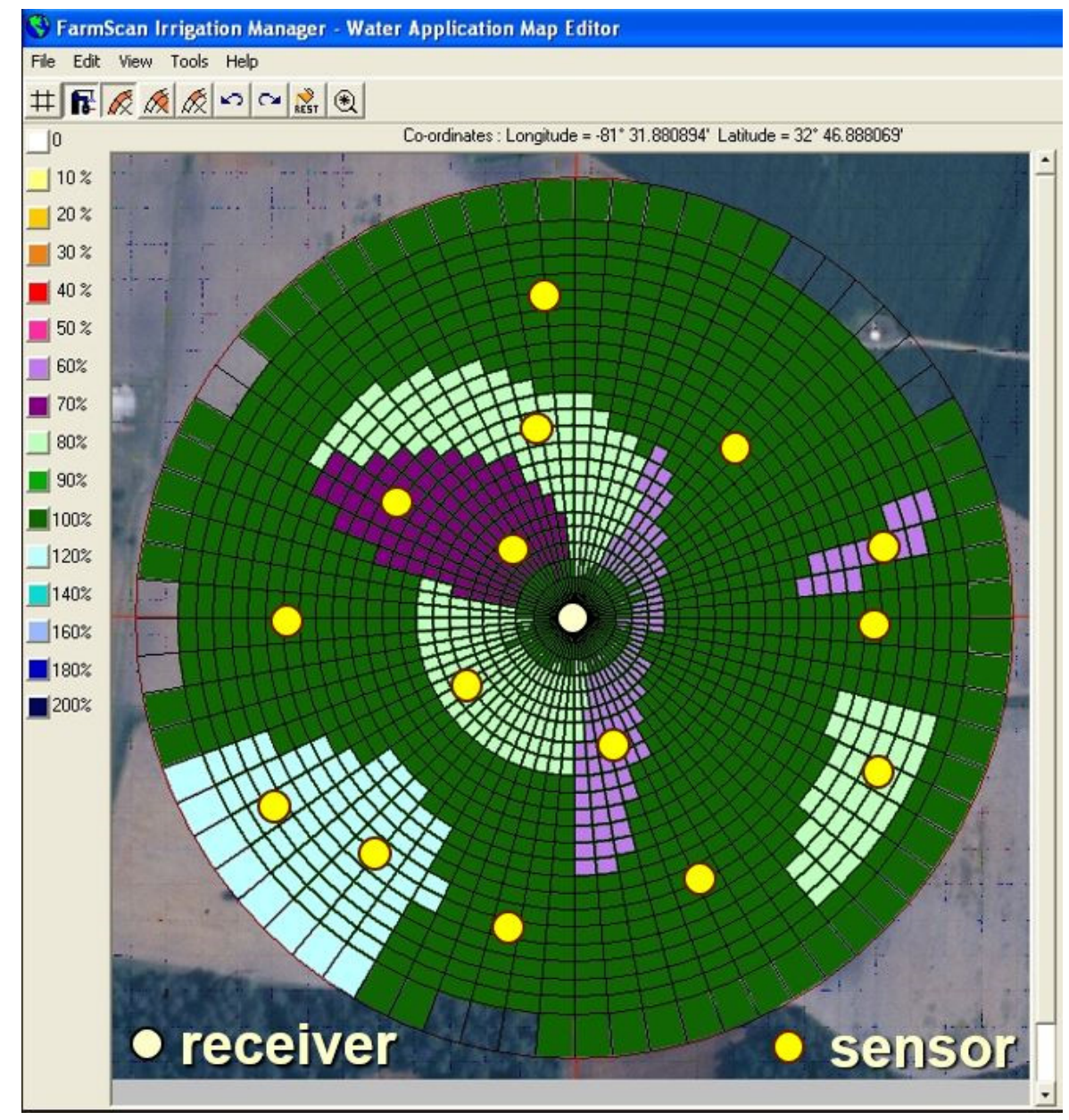

Figure 7. Variable rate irrigation prescription map for a 48-ha field in Georgia. Rectangular zones represent discrete areas that receive unique application rates. Colored areas represent irrigation management zones, and yellow circles show location of soil water sensors.

with using large numbers of soil water or plant sensors is inhibiting this approach. As a result, irrigation companies are exploring sensor-free, model-based solutions to dynamic VRI.

\section{IMPROVEMENTS IN IRRIGATION SCHEDULING TECHNOLOGIES}

Irrigation scheduling is defined as the process of determining when to irrigate and how much water to apply, based upon measurements or estimates of soil moisture or water used by the plant (ASABE Standards, 2015). Improvements in irrigation scheduling technologies have also played a role in improvements in U.S. cotton's improved CWP. In 2015, 250 of the 924 U.S. growers who responded to the survey reported irrigating cotton (Daystar et al., 2017). Of those who irrigated, $37 \%$ reported using an evapotranspirationbased scheduler and $26 \%$ said they used a sensor for irrigation scheduling. These responses are consistent with growers for other commodities where progress has been slow in increasing adoption of advanced irrigation scheduling methods (Lamm and Rogers, 2015). The following sections will review evapotranspiration- and sensor-based methods for irrigation scheduling in cotton, both in terms of what has already been applied at the farm level and current research to improve those methods. Additionally, the use of crop simulation models to aid in irrigation decisions will also be considered.

\section{EVAPOTRANSPIRATION-BASED SCHEDULING TOOLS}

Since the early 2000's, a great deal of water management research for cotton has focused on developing tools for evapotranspiration estimation and irrigation scheduling, based on the Food and Agriculture Organization of the United Nations, Irrigation and Drainage Paper No. 56 (FAO-56; Allen et al., 1998). The method uses a reference crop evapotranspiration commonly calculated from measured weather data at a location of interest, although Straatmann et al. (2018) investigated using atmometers in Missouri. A crop coefficient is used to estimate crop water use as shown in equation 3:

$$
E T_{c}=E T_{o} \times K_{c}
$$

where

$E T_{c}=$ daily crop water use $\left(\mathrm{mm} \mathrm{day}^{-1}\right)$,

$\mathrm{ET}_{\mathrm{o}}=$ short grass reference ET calculated using the Penman-Monteith equation $\left(\mathrm{mm} \mathrm{day}^{-1}\right)$, and

$K_{c}=$ a crop coefficient (unitless).

To make irrigation scheduling with the FAO 56 approach more accessible, several universities have developed tools to help producers implement the method, typically using locally 
available weather networks (e.g., Martin and Slack, 2005; Henggeler et al., 2010; Straatmann et al., 2018; Vellidis et al., 2016). Equation 3 is used to estimate crop water use and then a soil water balance is computed at a daily time step. Water inputs are typically from rainfall and irrigation events. In addition to water removals from crop water use, some irrigation schedulers include an estimate of rainfall runoff and percolation of soil water below the crop's rootzone. Once plant available water is predicted to be depleted to a predefined threshold, irrigation is recommended. Thresholds of $40 \%$ to $50 \%$ of plant available soil water are often used for cotton (Hunsaker et al. 2005; Farahani et al., 2008).

Allen et al. (1998) reported $\mathrm{K}_{\mathrm{c}}$ estimates for cotton, many cereal and other crops grown across the world; however, the applicability of those values in computing crop irrigation water requirements across soils, climates, and locations was found to introduce substantial errors in computed irrigation schedules (Howell et al., 2004; Farahani et al., 2008; Farg et al., 2012; Irmak et al., 2013; Payero and Irmak, 2013). For example, in a lysimetric study with cotton in a Mediterranean region of northern Syria, Farahani et al. (2008) found the Allen et al. (1998) tabulated values to be $24 \%$ greater than what they computed. Therefore, several crop coefficients have been developed for U.S. cotton by region as discussed in the follow sections.

\section{Far West Crop Coefficients}

Taghvaeian et al. (2012) found that tabulated $\mathrm{K}_{\mathrm{c}}$ values of FAO-56 and those utilized by the U.S. Bureau of Reclamation for estimating deliveries to irrigation districts assumed a shorter growing season and failed to capture the impacts of a heavy preseason irrigation event adopted by local producers in recent years in Southern California. In south central Arizona, Hunsaker et al. $(2005,2015)$ developed an evapotranspiration-based soil water balance tool following the FAO-56 dual crop coefficient method, which used normalized difference vegetation indices (NDVI) from multispectral remote sensing to estimate FAO-56 basal crop coefficients, and discussed the successes and limitations of this approach for cotton irrigation scheduling. Furthermore, Thorp et al. (2018) quantified cotton canopy cover with multispectral data from an unmanned aerial system. He then used the data to derive basal crop coefficients for FAO-56 cotton water use estimation and demonstrated how the methodology could facilitate selection of cultivars with favorable water use characteristics in a cotton breeding program. While remote sensing techniques for crop coefficient estimation require further development, the Hunsaker et al. (2005) implementation of the FAO56 soil water balance model with standard FAO-56 crop coefficients is still a primary tool for irrigation management decisions in cotton research. An example is the Arizona Irrigation Scheduling System (AZSCHED, https://cals.arizona.edu/ crop/irrigation/azsched/azsched.html) discussed by Martin and Slack (2005).

\section{Southwest Crop Coefficients}

Howell et al. (2004) developed single crop coefficients (i.e., where soil evaporation and plant transpiration were combined in one coefficient) for upland cotton under dryland, deficit, and full irrigation (i.e., meeting full crop water requirements) by MESA at Bushland, Texas. The location was a semiarid climate with strong regional advection and was considered very marginal for cotton production because of limited heat units and relatively short growing seasons. The crop coefficients were developed from measurements of actual crop ET by large weighing lysimeters (Marek et al., 1988; Howell et al., 1995; Marek et al., 2014), and used the ASCE Standardized Penman-Monteith equation for a short reference crop (ASCE-EWRI, 2005). Weighing lysimeters were also used by Ko et al. (2009) in a semiarid climate in southern Texas (Uvalde) to develop $\mathrm{K}_{\mathrm{c}}$ values for cotton. Their values ranged from 0.2 to 1.5 and tended to be greater early and late season relative to those reported by Howell et al. (2004). An example of a grower oriented tool to assist with irrigation scheduling in the SW is the Texas ET Network (https://texaset.tamu.edu/).

\section{Midsouth Crop Coefficients}

Anapalli et al. $(2019,2020)$ quantified $\mathrm{ET}_{\mathrm{c}}$ from irrigated cotton (cv. Delta Pine Land 1522) in a Tunica clay soil, in the Lower Mississippi Delta in 2017 and 2018, using eddy covariance (EC) technology (fig. 8). In the experiment, a sonic 3-D anemometer and an open-path infrared gas analyzer were used for measuring water flux data in the constant flux layer above the cotton canopy. Measured $\mathrm{ET}_{\mathrm{c}}$ was used to quantify $\mathrm{K}_{\mathrm{c}}$ for reference crop ET computed from weather data (Anapalli et al., 2020). The $\mathrm{K}_{\mathrm{c}}$ can be used for developing a location (soil and weather) specific irrigation scheduling system for cotton. Two-year average $\mathrm{K}_{\mathrm{c}}$ values ranged from 0.36 to 0.99 . Fisher (2012) also developed $\mathrm{K}_{\mathrm{c}}$ values for cotton in the same region using small weighing lysimeters and reported $\mathrm{K}_{\mathrm{c}}$ varying between 0.2 and 0.6 during the early growth stage and between 1.1 and 1.3 during the peak growth stage. The Crop Water Use Application (CWUA) from the University of Missouri (http://ag3.agebb.missouri.edu/horizonpoint/cropwater/) and the Arkansas Irrigation Scheduler (www.irrigweb.uaex.edu) are examples of ET-based irrigation scheduler in the MS. ET-based irrigation scheduling might benefit from a more regional, rather than local approach in the MS. The size of the region and similar conditions throughout the MS suggest that one system could

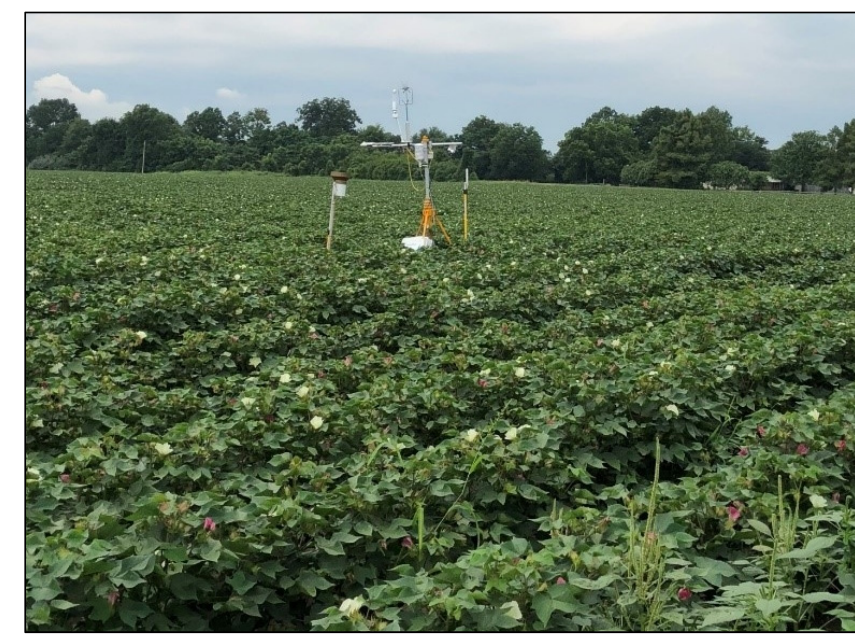

Figure 8. Eddy covariance system installed in a Mississippi cotton field to measure net ecosystem exchange of $\mathrm{CO}_{2}$ and water from Anapalli et al. (2019). 
be used by all farmers in the region; however, many funding sources are resistant to sharing resources among states, thereby inhibiting multi-state collaboration.

\section{Southeast Crop Coefficients}

Vellidis et al. (2016) developed $\mathrm{K}_{\mathrm{c}}$ values using a soil water balance approach and accumulated heat units for central and southern Georgia (fig. 9). That $\mathrm{K}_{\mathrm{c}}$ curve was derived to support the SmartIrrigation Cotton App (hereafter referred to as Cotton App), which is a recently developed weatherbased irrigation scheduling tool that operates on a smartphone platform. It is one of several similar apps included in the SmartIrrigation App Suite developed jointly by the University of Georgia and the University of Florida (www.smartirrigationapps.org). The app can download weather data from local weather station networks, incorporate rainfall data from grower managed rain gages, and integrate data from the national weather service (FRET, https://www.weather.gov/cae/fretinfo.html). The Cotton App has consistently outperformed calendar-based scheduling methods in yield, irrigation water applied, and ICWP, and its performance has been comparable to sensor-based scheduling methods (Vellidis et al., 2016).

\section{Challenges to ET-Based Irrigation Scheduling}

A continuing challenge for scheduling methods that rely on a crop coefficient is determining a $\mathrm{K}_{\mathrm{c}}$ that is valid for both the local environment and the cotton variety grown. Since the introduction of biotechnology to cotton varieties in the mid-1990s, the numbers of varieties available for farmers have increased and they often have different season lengths (e.g., Wiggins et al., 2013). The differences in canopy development rates and season lengths between varieties can have a large impact on the estimated $\mathrm{K}_{\mathrm{c}}$ if changes in $\mathrm{K}_{\mathrm{c}}$ are estimated from days after planting or growing degree days. Another challenge is that publicly available weather data are not always appropriate for agricultural purposes due to differing values associated with non-agriculturally based siting (e.g., airports) that can lead to erroneous calculated $\mathrm{ET}_{\mathrm{c}}$ rates $(\mathrm{Ma}-$ rek et al., 2010). An additional challenge is accurately estimating effective rainfall, particularly from intense rainfall

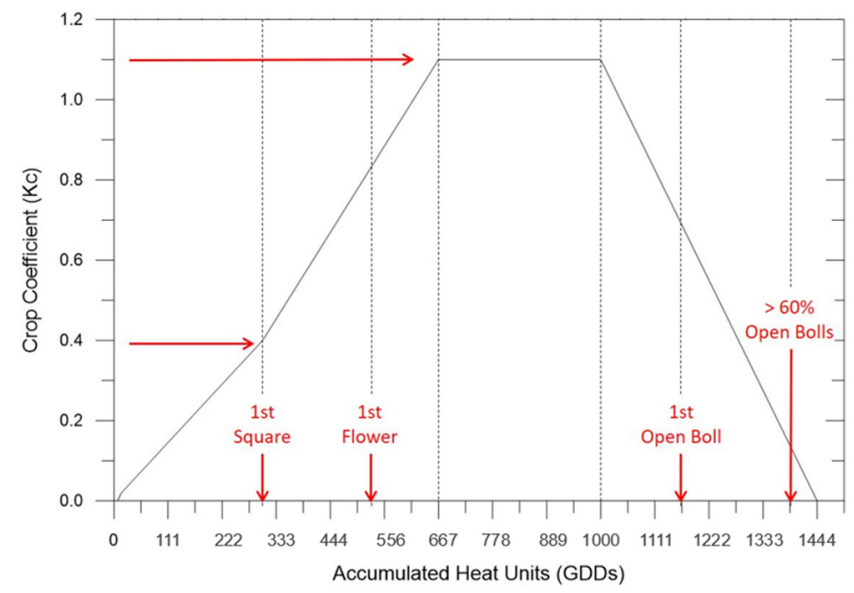

Figure 9. Crop coefficient (Kc) curve used by the SmartIrrigation Cotton App (Vellidis et al., 2016). Phenological stages are driven by growing degree days (GDDs, ${ }^{\circ} \mathrm{C}$ using a based temperature of $15.6^{\circ} \mathrm{C}$ ) and shown in red font. events where a large percentage of the rainfall is lost as field runoff.

\section{SENSOR-BASED TOOLS}

Sensors that measure properties of the soil and of the crop have been used for scheduling cotton irrigation for years, starting with water-based tensiometers more than 40 years ago. Sensor-based tools for monitoring water resources and scheduling irrigation range from simple manual hand tools, methods with periodic sampling, and automated electronicsensing systems for continuous, season-long monitoring. While manual methods involving soil probes or augers provide access to real, tangible conditions in the soil and root zone, they require time and effort to visit and sample the fields, as well as some experience in interpreting the look and feel of the soil to adequately evaluate water conditions and determine whether sufficient water is available to the crop. The ability to remotely monitor both soil and crop sensors via affordable cellular networks has greatly increased cotton grower interest in these tools.

\section{Soil Sensors}

A popular approach tor irrigation scheduling is to use the sensors measuring soil water and apply water when there is a soil water deficit that would be anticipated to cause plant water stress. Various types of soil water sensing devices have been developed and are commercially available. Some of these are capable of wirelessly transferring the data collected from their sensors. Neutron probes have been shown to be one of the most reliable tools for measuring soil water content (Evett et al., 2008), but their use is limited by cost and special requirements associated with handling its radioactive source. Electromagnetic sensors, such as electrical capacitance and resistance type sensors, and time-domain reflectometry (TDR) devices have been developed and adopted to measure soil water for irrigation scheduling (Fares and Alva, 2000; Seyfried and Murdock, 2001; Dukes and Scholberg, 2004; Evett and Parkin, 2005; Miranda et al., 2005; Vellidis et al., 2008; Schwartz et al., 2016; O'Shaughnessy and Sui, 2018; Sui et al., 2018). Researchers have shown that soil water sensors can effectively be used for irrigation scheduling. However, procedures for proper installation, calibration, and maintenance of soil water sensing devices are critical for the success of the sensor-based irrigation scheduling (Yoder et al., 1997; Leib et al., 2003; Evett et al., 2006; Sui et al., 2012).

Researchers have evaluated the use of electronic monitoring systems for irrigation scheduling under a variety of environmental, cropping, and cultural conditions (Phene et al., 1989; Jones, 2006; Gutiérrez et al., 2013; Haule and Michael, 2014; Soulis et al., 2015; Payero et al., 2017; Fisher et al., 2018, 2020). Work undertaken explicitly for cotton production has also been reported (Bockhold et al., 2001; Thomson et al., 2002; Bellamy et al., 2009; Leib et al., 2015; O'Shaughnessy et al., 2015; Meeks et al., 2017). Many of these efforts have dealt with development of the electronic systems, field implementation issues, wireless and cellular data transmission, and methods to interpret sensor data and develop scheduling strategies. Three example case studies of using soil water monitoring (SWM) systems for irrigation 
scheduling specifically for cotton will be discussed to demonstrate the progress that has been made.

\section{Oklahoma Case Study for SWM Systems}

Sensor-based irrigation scheduling studies at Oklahoma State University have been focused on two factors that appear to contribute to poor adoption rates. The first factor is the accuracy and reliability of soil water sensors under field conditions. A significant portion of irrigated cotton in Oklahoma is in areas characterized by greater levels of soil salinity and clay content, which have negative effects on sensor accuracy and reliability. An experiment conducted in southwest Oklahoma showed that under elevated soil electrical conductivity (EC of $7.0 \mathrm{dS} \mathrm{m}^{-1}$ ) and clay content $(39 \%)$, the error of five widely-used soil water sensors ranged from 0.05 to $0.23 \mathrm{~m}^{3} \mathrm{~m}^{-3}$ (Datta et al., 2018). These errors were from 1.1 to 20 times larger than the errors of the same sensors under reduced soil EC $\left(1.2 \mathrm{dS} \mathrm{m}^{-1}\right)$ and clay content (13\%). In the case of one sensor, the data gap was $21 \%$ under greater salinity and clay, compared to less than $1 \%$ under reduced salinity and clay content (Datta et al., 2018). These findings are consistent with the recommendation of some previous literature that site-specific calibrations must be conducted to achieve accuracy levels required for implementing effective irrigation scheduling. Site-specific calibration, however, significantly adds to the complexity and cost of utilizing soil water sensors. Errors in estimating the lower and upper thresholds of soil water for irrigation scheduling (wilting point and field capacity) could add to the errors in sensor readings and further impact day-to-day irrigation scheduling.

A second factor that may impact adoption of sensor technologies is the feasibility of integrating sensors with existing on- and off-farm irrigation management regimes. For instance, cotton producers who receive water from an open canal network on a fixed rotation do not have the flexibility of those who pump from private irrigation wells in deciding when and how much water to apply. In situations like this, investing in sensor technologies may not appear to be justi- fied. However, there may still be opportunities for use of affordable sensing technologies to improve irrigation management under less flexible conditions. In another study at Oklahoma State University, the effects of irrigation termination date on cotton yield and water conservation was evaluated during a three-year period. The irrigation termination date can be controlled by producers even if they have no control over irrigation intervals during the growing season. The results showed that a significant amount of water can be saved by terminating irrigations earlier and soil water sensors were found to be effective in optimizing the timing of irrigation termination. The impact on cotton yield and fiber quality was variable, depending on the late-season precipitation (Masasi et al., 2019).

\section{Mississippi Case Study for SWM Systems}

A practical method for sensor-based irrigation scheduling in cotton was developed and used in the Mississippi Delta (Sui, 2018). Soil water sensors were installed in a cotton field and soil volumetric water content (VWC) was automatically measured by the sensors at a time interval of one hour during the cotton growing season. Weights assigned to the measurements at depths of 15,30 , and $61 \mathrm{~cm}$ were 0.45 , 0.35 , and 0.2 , respectively, based on the root distribution observed in the soil profile (fig. 10). Irrigation events were triggered when the percentage of plant available water (PAW) dropped to approximately 50\%. An innovative springmounted antenna allowed in-season cultural practices (Sui, 2018).

\section{Tennessee Case Study for SWM Systems}

The Tennessee Cooperative Extension Service began a series of irrigation experiments aimed at improving cotton yield in the loess hills of West Tennessee, which is near the northern limit of cotton production. One of the primary objectives was to provide research-based recommendations for irrigation management tools such as matric potential sensors and water balances. Growth stage specific irrigation thresholds were established for both deep silt loam soils (Gwathmey et al., 2011; Zhou et al., 2016) and soils with reduced

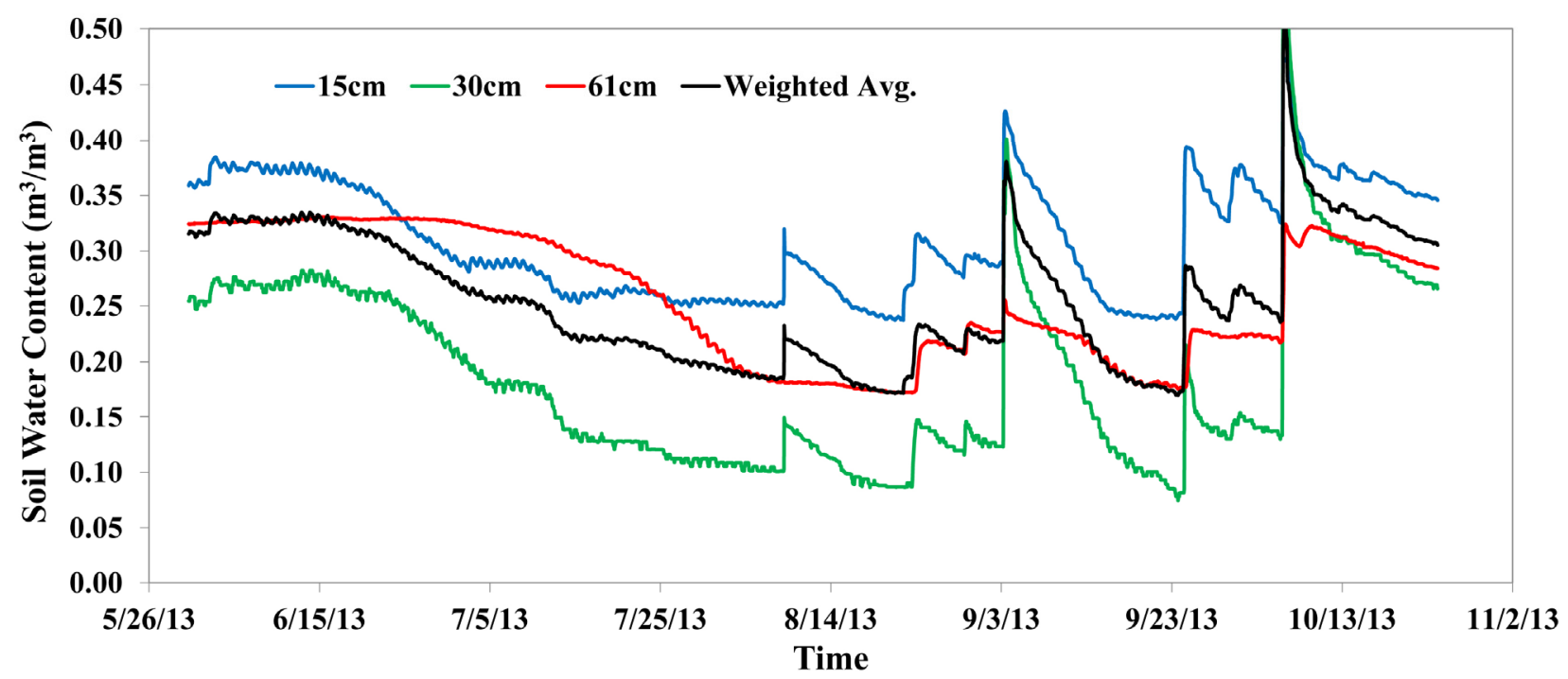

Figure 10. Sensor-measured soil volumetric water contents at three depths and the weighted average. 
water holding capacity (Grant et al., 2017a, b; Wiggins et al., 2014). As expected, the reduced water holding capacity soils typically required irrigation earlier. Results from these studies have been used for irrigation scheduling demonstrations on producer fields in cooperation with extension agents and crop consultants. Additionally, sensor and water balance irrigation scheduling has also been presented at many workshops. The most complete summary of cotton irrigation recommendations resides in a University of Tennessee UTExtension publication entitled, "The Basics of Cotton Irrigation in Tennessee" (Leib et al., 2018). As of 2019, four Tennessee crop consultants were providing irrigation scheduling service to 77 row crop producers on 8,340 ha.

Starting in 2015, irrigation recommendations were incorporated into the Management of Irrigation Systems in Tennessee (MOIST + ) spreadsheet that automatically processed field specific matric potential and water balance (evapotranspiration \& rainfall) data in real time using dataloggers equipped with cellular modems. The process of interpreting sensors and testing MOIST+ with producers has required moving beyond clearly defined soil types to address the reality of soil variability found in producers' fields. Often, sensor stations were placed at multiple locations in a field due to soil differences and decisions were made to either irrigate the field as a whole or according to several pie-shaped zones within the field (Leib et al., 2015). Irrigation zones (areas of the field receiving the same rate of water) were delineated using the data sources available to producers such as satellite imagery, yield maps, electrical conductivity and soil water properties from intense soil sampling (Haghverdi et al., 2016; Haghverdi and Leib, 2018; Haghverdi et al., 2018, 2019).

\section{Crop-Based Sensor Approaches}

In addition to inferring crop condition based on soil water availability from sensors, direct measures of crop conditions have been used. The most widely studied crop-based approaches that have had on-farm use for irrigation scheduling are methods that rely on canopy temperature (Tanner, 1963; Wiegand and Namken, 1966; Jackson, 1982; Gardner et al., 1992a, b). The temperature of the plant canopy is related to the consumption of energy since a water-evaporating surface is generally cooler than a non-evaporating surface. Thus, the canopy temperature of a well-watered crop will, in general, be less than the canopy temperature of crop experiencing a water deficit. The canopy structure of cotton makes canopy temperature monitoring relatively straightforward. Irrigated cotton often "closes" its canopy which reduces the contribution of soil background to canopy temperature scenes. There is typically a period of 40 days after planting when the reliable measurement of canopy temperature is difficult due to the impact of soil background in the field of view of the sensors; however, some correction is possible using spectral indices (Colaizzi et al., 2003).

A large portion of research to use canopy temperature for irrigation scheduling has been conducted on cotton (Wanjura et al., 1988, 1990; Colaizzi et al., 2003, 2016; Peters and Evett, 2008; O'Shaughnessy and Evett, 2010; O'Shaughnessy et al., 2011, 2015). Several algorithms that use canopy temperature have been developed and applied to cotton, including the crop water stress index (CWSI; Jackson, 1982), water deficit index (WDI; Moran et al., 1994), time-temperature threshold (TTT; Wanjura et al., 1988, 1995), and a variant that combines the CWSI and TTT, termed the integrated crop water stress index (iCWSI; O'Shaughnessy et al., 2015).

\section{The Crop Water Stress Index (CWSI) Approach}

The CWSI is a means of associating measured canopy temperatures with crop water status (Jackson et al., 1981). The CWSI approach treats the crop canopy as an evaporating surface that consumes water in proportion to its size and environmental demand. The temperature of the canopy is defined by upper and lower bounds that describe both transpiring and non-transpiring conditions. Frequent in-season comparisons of the crop canopy temperature with the estimated temperature of a "well-watered" crop canopy are the basis of CWSI approaches (Idso, 1982). Advantages of the CWSI method include; a strong basis in physics, simple instrumentation, and capability for automation. Weaknesses include the need for biological scalers (e.g. canopy resistance) and information on local agronomic factors. A midday CWSI of 0.2 has been used as a threshold to trigger irrigation for cotton (Reginato, 1983).

\section{Temperature-Time Threshold Method}

In the late 1980's the Temperature-Time Threshold method (TTT) for irrigation management by canopy temperature was developed (Upchurch et al., 1996; Wanjura et al., 2006). The TTT method is also sometimes referred to as the BIOTIC (Biologically Identified Optimal Temperature Interactive Console) approach. The BIOTIC temperaturebased method is based on the concept that a plant has an optimal temperature for metabolism and that timely irrigation results in canopy temperatures that are conducive to the growth and development of the plant. In use, the BIOTIC approach continuously compares canopy temperature to a fixed species-specific biologically-based estimate of the optimum temperature of the crop. Canopy temperature values in excess of this "threshold temperature" are used to assess the water status of the crop. When canopy temperatures exceed the temperature threshold, plant water status may be less than optimal. Several methods are available to estimate the biological optimum of a given crop species and when an irrigation system cannot be triggered immediately when the temperature exceeds that threshold, an accumulated time above the temperature threshold can be used to trigger irrigation (Upchurch et al., 1996; Mahan et al., 2005). A temperature threshold of $28^{\circ} \mathrm{C}$ is typically used for irrigation scheduling in cotton and an accumulated time threshold of 4 hours was found to decrease irrigation without yield loss when compared to time thresholds of 2 and $2.5 \mathrm{~h}$ (Wanjura et al., 1995).

\section{The Future of Canopy Temperature-Based Irrigation Management.}

While both the CWSI or BIOTIC irrigation approaches show potential to improve irrigation management, they are not currently widely used in production agriculture. Given 
that canopy temperature measurement approaches have been well-researched, their lack of adoption in agricultural production is partly due to the lack of affordable and commercially-available systems. Based on several years of experience, field IRT systems would ideally be as follows: 1) rugged, 2) capable of near continuous monitoring, 3) capable of capturing $>90 \%$ of data during a season, 4) connected wirelessly for data transmission, and 5) capable of a season of data collection without battery changes. It is anticipated that precision in irrigation scheduling will be improved when both canopy and soil water sensors can be integration with crop and weather forecast models (Holloway-Phillips et al., 2008), and it is still to be determined if such an integration could be made to provide a return on investment to a cotton farmer.

\section{Obstacles to Adoption of Sensor-Based Irrigation Methods}

A rough comparison of U.S. cotton water and yield values to what is currently achieved in other cotton production settings suggests that there is still opportunity for improvement. Current data suggest that average CWP in U.S. cotton is approximately $0.23 \mathrm{~kg} \mathrm{~m}^{-3}$ (Zwart and Bastiaanssen, 2004). Recent discussions with representatives of an Australian irrigation management company (J Mahan, USDA-ARS, Lubbock, Tex., personal communication) suggest that CWP in well-watered Australian production, aided by soil water sensors, is generally in the range from 0.25 to $0.35 \mathrm{~kg} \mathrm{~m}^{-3}$. While there are many differences between the U.S. and AU production systems, these numbers suggest that there is still room for improvement in U.S. cotton irrigation management. Increased use of sensor-based irrigation methods in U.S. cotton may help to improve the water use and yield relationships.

The development of sensors capable of monitoring soil and crop water status in near-real time over the course of a growing season has expanded over the past few decades, offering the promise of improved irrigation management. Sensor-based irrigation scheduling adoption is still small based on data from USDA irrigation management survey data as shown in figure 11 (USDC, 1990; USDA-NASS, $1994 ; 1999 ; 2004 ; 2010 ; 2014 ; 2019)$. Clearly the national data on approximately 81,000 ha of irrigated land includes a wide range of crops and regions but it is apparent that the vast majority of irrigation decisions are still made on the basis of visual "crop conditions" and the "feel of the soil". These two methods have been used since the advent of crop irrigation. The total irrigation management that involves science-based decisions (e.g., sensors and other technologies) remains small at approximately $17.5 \%$ (i.e., soil probes for $9 \%$, plant sensors for $1 \%$, and ET for $7 \%$ ).

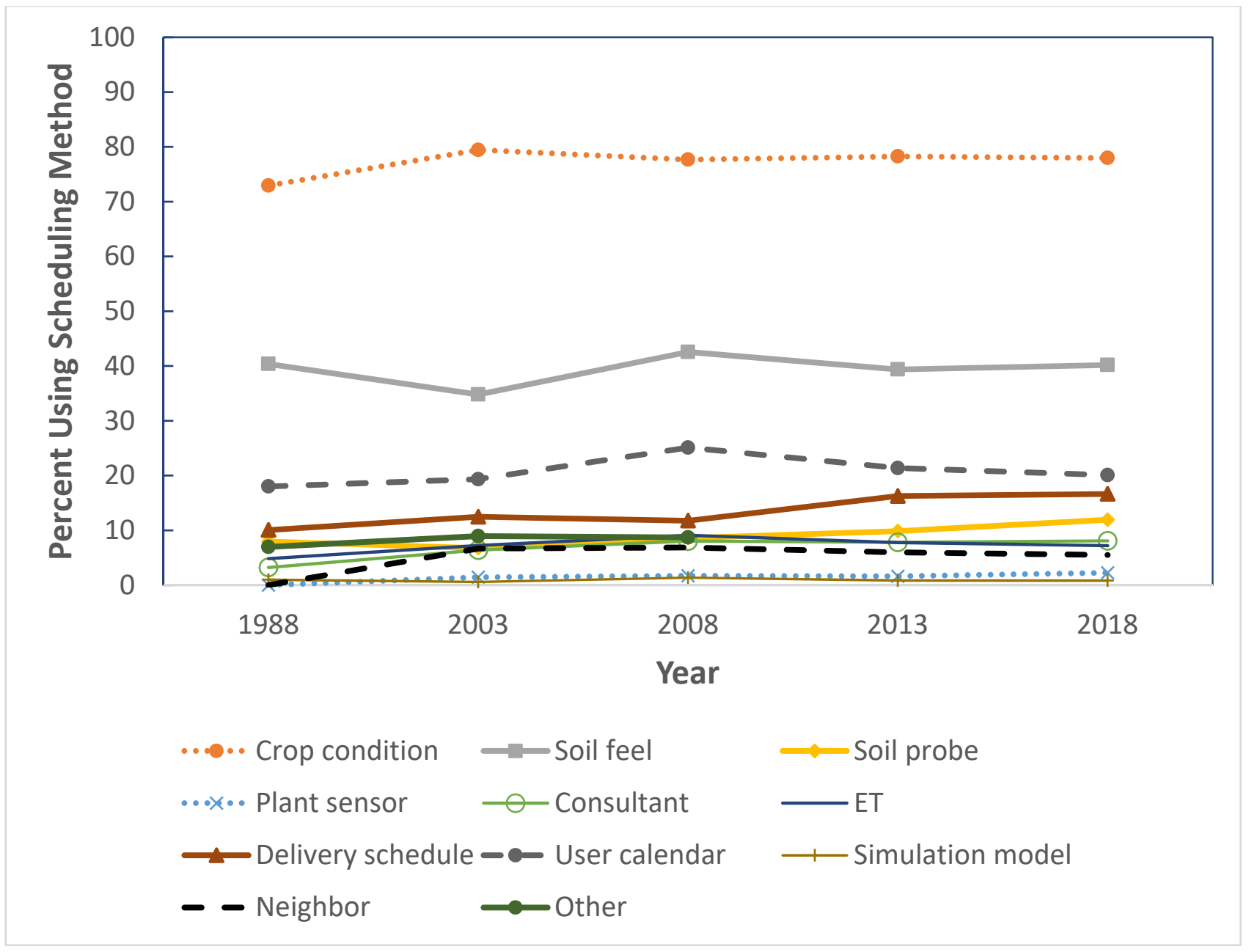

Figure 11. Use of irrigation scheduling methods over time (USDC, 1990; USDA-NASS, 1994;1999; 2004; 2010; 2014; 2019). 
Given the numerous studies that have found ET-based and sensor-based irrigation scheduling methods are accurate, there have been other factors limiting the adoption of these technologies. In some cases, it is lack of time for a farm manager to digest data from sensors deployed in multiple fields even if delivered to their office wirelessly (Midgley, 2019). Other factors include the costs of the sensors and lack of studies that document return on investment; and the fact that the timeliness of other farm operations (e.g., pest control) take precedence over irrigation events (Evans et al., 2013). In light of the lagging adoption, the focus needs to shift from the accuracies of the various methods to how accurate irrigation scheduling can increase yield and return on investment.

\section{CROP Simulation MODELING TO IMPROVE IRRIGATION DECISIONS}

Crop growth models have been increasingly used to suggest efficient irrigation management strategies for increasing CWP in cotton production systems. After a thorough evaluation based on measured data, crop models serve as useful tools for simulating numerous hypothetical irrigation experiments inexpensively and quickly and assist in on-farm irrigation decision making. In a study at Halfway in the Texas High Plains (THP) region, Ale et al. (2020) used the CROPGRO-Cotton module in the Decision Support System Agrotechnology Transfer (DSSAT) Cropping System Model (CSM) to suggest optimum irrigation termination periods for cotton in dry, normal, and wet years.. While early irrigation termination causes yield loss, late termination results in wastage of irrigation water without any yield increase, delayed harvest, and increased pest management costs. Long-term simulations (1978-2016) with multiple irrigation termination dates found that the first or second week of September was ideal for terminating irrigation for cotton with full and deficit irrigation in normal years. Ideal irrigation termination periods in wet or dry years were found to be a week earlier or later than those in normal years, respectively. Vories et al. (2011) also evaluated the optimal time for irrigation termination in cotton using data collected across the MS and found that for locations north of $34^{\circ} \mathrm{N}$ latitude, the amount of time accumulated after the plant had five nodes after white flower has potential to define when to end the irrigation season.

In another THP cotton modeling study, Himanshu et al. (2019) suggested efficient crop-growth-stage-based irrigation strategies for the Southern High Plains region under nine different climate variability classes and eight different levels of irrigation water availability using the DSSATCSM-CROPGRO-Cotton model. They found the peak bloom growth stage to be the most sensitive stage to water stress, and imposing water deficit during this stage resulted in the smallest ICWP and seed cotton yield. They have also found that imposing water deficit in the initial or final growth stages had little effect on seed cotton yield.

Crop growth models are also very useful for assessing the impacts of projected changes in climate on seed cotton yield and irrigation water use, and thereby assist in developing efficient crop and irrigation management strategies under projected future climate scenarios. They are also useful for identifying potential adaptation strategies and cultivar traits that can maintain seed cotton yields while efficiently utilizing irrigation water. Adhikari et al. (2016) simulated the impacts of climate change on cotton irrigation water use and yield in the THP, using the future climate data projected by three Global Climate Models and found yields would be sustained or increased due to forecasted increased $\mathrm{CO}_{2}$. However, assuming the irrigation water availability would decrease by $40 \%$ in 2050 as predicted for the region, cotton yields would decrease a similar amount (37\% to 39\%).

The DSSAT-CSM CROPGRO-Cotton model was also evaluated using data from five cotton growing seasons at Maricopa, Arizona (Thorp et al., 2014) and was developed as an in-season decision tool for irrigation scheduling during the 2014 and 2015 Arizona cotton growing seasons (Thorp et al., 2017). These experiences, in part, led DeJonge and Thorp (2017) to incorporate a new evapotranspiration option in the DSSAT-CSM, based on current advances in standardized evapotranspiration methods, including the ASCE Standardized Reference Evapotranspiration Equation (Walter et al., 2005) combined with the FAO-56 dual crop coefficient procedure (Allen et al., 1998). With the updated evapotranspiration methods, the CSM-CROPGRO-Cotton model could match or exceed the accuracy and capability of an FAO-56 spreadsheet tool for cotton water use quantification and irrigation scheduling (Thorp et al., 2017). A similar standardized evapotranspiration option was added to the Cotton $2 \mathrm{~K}$ model, which led to significantly better evapotranspiration simulations(Thorp et al., 2019).

After updating the evapotranspiration methods in CSMCROPGRO-Cotton, the model was used to schedule irrigation for cotton field studies with different irrigation rates and timings during the 2016, 2017, and 2018 growing seasons in Maricopa, Arizona (Thorp et al., 2020). While the studies demonstrated that model recommendations were reasonable for achieving greater yield with adequate water use efficiency, results also suggested that opportunities exist to improve cotton production outcomes by fine-tuning irrigation recommendations from this model. CSM-CROPGRO-Cotton was also used to evaluate the long-term effects of sitespecific irrigation management on Arizona cotton production variables (Thorp, 2020). Cotton yield, irrigation requirements, water use efficiency, and marginal net return with site-specific irrigation were often not different from that for conventional uniform irrigation $(\mathrm{p}>0.05)$, primarily because the soil water holding capacities for most soils at the study site were enough to sustain cotton production at full potential with weekly uniform irrigation management. The findings from this simulation study and a related field study (Thorp et al., 2020) suggested that future irrigation management research for Arizona cotton should focus on improving methodologies for temporal irrigation scheduling (using cotton simulation models) rather than methodologies for spatial irrigation applications.

\section{Agronomic And Genetic Advances}

It is important to acknowledge that independent of advances in irrigation technologies, cotton has become more 
productive due to improved agronomic management and genetic improvements. Identification of key growth stages where cotton is less drought tolerant has allowed better use of water when well capacities are limited.

\section{GROWTH STAGE RESPONSE TO IRRIGATION}

Optimizing irrigation strategies for specific fields, growing conditions, and application methods can significantly improve CWP. In the SW, early season evaporation losses can be greater (Lamm et al., 2019) and irrigation capacities are significantly less than cotton water requirements (Bordovsky et al., 2015). The prevailing strategy, carried forward from surface irrigation days, has been to "bank" irrigation water in the soil profile at preplant and during the early growing season to reduce cotton water stress later in the season. Irrigation timing experiments using the LEPA method have shown that eliminating irrigation during the period from germination to cumulative growing degree day of 550 $\left({ }^{\circ} \mathrm{C}\right.$, base $\left.15.6{ }^{\circ} \mathrm{C}\right)$ used $20 \%$ less seasonal irrigation with less than $2 \%$ yield loss compared to corresponding treatments irrigated at capacities of 3.2 and $6.4 \mathrm{~mm} \mathrm{~d}^{-1}$ throughout the typical irrigation period (Bordovsky et al., 2015). This was attributed to reduced early season evaporation losses and reduced early season plant growth that could not be supported with available irrigation late in the season. Meeks et al. (2017) also found that cotton yields were less sensitive to water stress prior to flower bloom in a humid environment. However, this does not mean cotton is completely insensitive to early season water stress. For example, Vories et al. (2007) showed that delaying the first irrigation and allowing early season stress can result in a yield loss. A similar SDI timing experiment (Bordovsky, 2020) included preplant irrigations of approximately 50 and $100 \mathrm{~mm}$ and early season irrigation capacities of $0.0,2.5$, and $5.1 \mathrm{~mm} \mathrm{~d}^{-1}$ resulting in six treatments plus a "preplant only" check. Based on the 5-year study, the greatest return on investment was in treatments with no or limited preplant and early season irrigations (fig. 12).

\section{Genetic GaINS}

Increases to cotton's genetic yield potential has also been an important factor in cotton's increased CWP over the last 40 years. As indicated by equation 1 , an increase in yield without an increase in water use increases CWP. Liu et al. (2013) estimated the rate of lint yield increase in Australia at $7.0 \mathrm{~kg} \mathrm{ha}^{-1} \mathrm{yr}^{-1}$ from 1980 to 1994 and $18.3 \mathrm{~kg} \mathrm{ha}^{-1} \mathrm{yr}^{-1}$ from 1995 to 2009 . In their analysis, productivity increases were due to genetics $(48 \%)$, management $(28 \%)$ and genetics $\times$ management (24\%). For U.S. cotton, Campbell et al. (2014) showed that on-farm lint yields increased at a rate of $13.3 \mathrm{~kg}$ $\mathrm{ha}^{-1} \mathrm{yr}^{-1}$ from 1981 to 2012 (fig. 13) and at a much greater rate from 1996 to $2012\left(22.4 \mathrm{~kg} \mathrm{ha}^{-1} \mathrm{yr}^{-1}\right)$ that corresponded with the widespread adoption of transgenic trait technologies and production systems. The field level data were closely mirrored by results from regional cotton variety trials conducted under more rigid protocols where Campbell et al. (2014) demonstrated significant genetic gains at a rate of $21.6 \mathrm{~kg} \mathrm{ha}^{-1} \mathrm{yr}^{-1}$ from 1996 to 2012. Collectively, these studies demonstrate that recent gains (1996 to present) in productivity increases are occurring rapidly in large portion

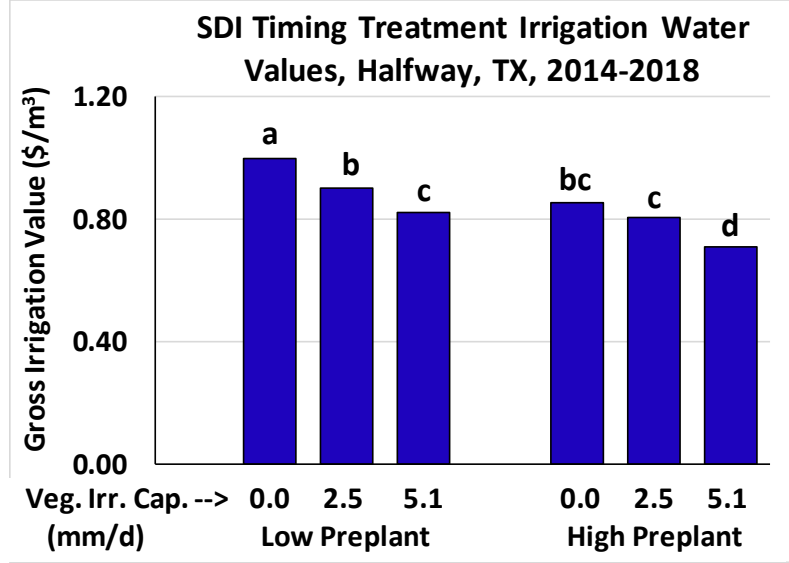

Figure 12. Irrigation water values of preplant and vegetative period irrigation timing treatments using subsurface drip irrigation at Texas A\&M AgriLife Research, Halfway, Tex., 2014-2018 (Bordovsky, 2020).

to private and public sector investments in genetic improvement. Recent productivity increases also provide evidence that the yield stagnation observed from 1970 to 1985 (Meredith and Bridge, 1984) has been addressed. Further, these recent estimates of genetic gain suggest that a yield plateau, which was feared in the 1980s, has not been reached thus far and future genetic gains should continue to increase on-farm productivity.

\section{ADDitional Agronomic FACTORS IMPACting COTTON's CWP}

Improved agronomic practices have also led to cotton's improve CWP over the last forty years, including improved insect pest control. Many cotton pests damage fruiting structures, decreasing yield without altering or in some cases, increasing water use (Holman and Oosterhuis, 1999). An important contributor to improved cotton productivity from the 1980s to early 2000s was the impact of the boll weevil eradication program; by 2002 most states had eliminated the boll weevil from their borders (Hardee and Harris, 2003) and only a small area of southern Texas is currently impacted by the boll weevil. Transgenic technologies have improved control of the bollworm and the adoption of integrated pest management has reduced damage from arthropods (Luttrell et al., 2015).

Other aspects of agronomic management have improved with $80 \%$ of U.S. cotton producers reporting the use of soil sampling for fertilizer management in 2015 (slight increase from $75 \%$ in 2008) and $46 \%$ using grid-based soil sampling for site specific management in 2015 (Daystar et al., 2017). Overall, use of precision technologies (inclusive of autosteer, yield monitors, and grid sampling) increased from $60 \%$ in 2008 to $84 \%$ in 2015 (Daystar et al., 2017). In 1990, only $13 \%$ of U.S. cotton area were managed using conservation tillage practices (CTIC, 2020) compared to estimated $65 \%$ in 2015 (Daystar et al., 2017). Based on an analysis by Morison et al. (2008), it can be inferred that all of these agronomic management improvements have been partly responsible for cotton's increased CWP. 


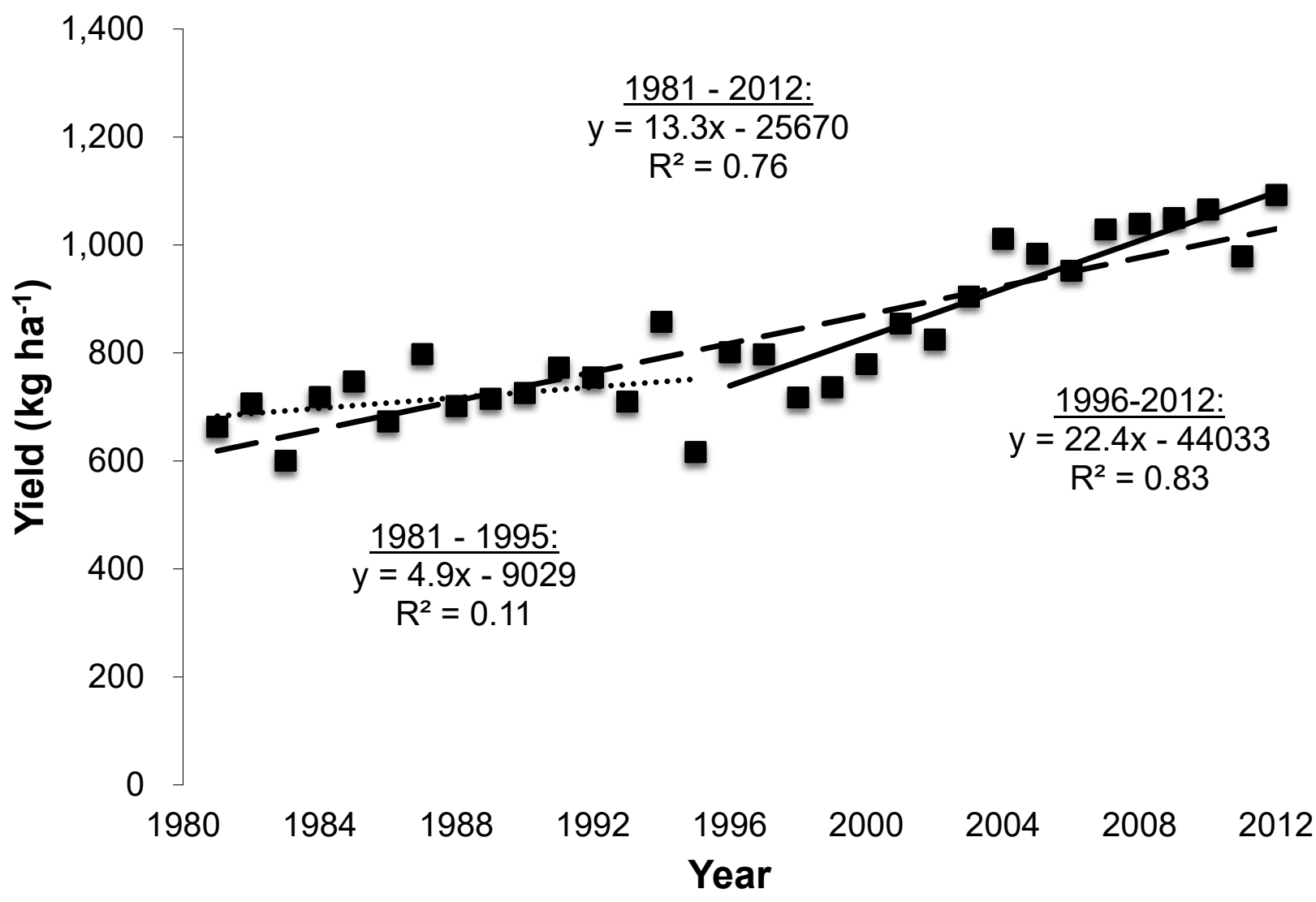

Figure 13. Farm level lint yield versus time (Campbell et al., 2014).

\section{FUTURE STRATEgies TO FURTHER}

\section{INCREASE CWP}

The American Cotton Producers of the National Cotton Council have set a 2025 goal to increase ICWP $18 \%$ when compared to $0.21 \mathrm{~kg} \mathrm{~m}^{-3}$ in 2015 (NCC, 2018). Figure 14 shows that goal is in line with historic trends and as outlined in this article. Many advances have contributed to that trend,

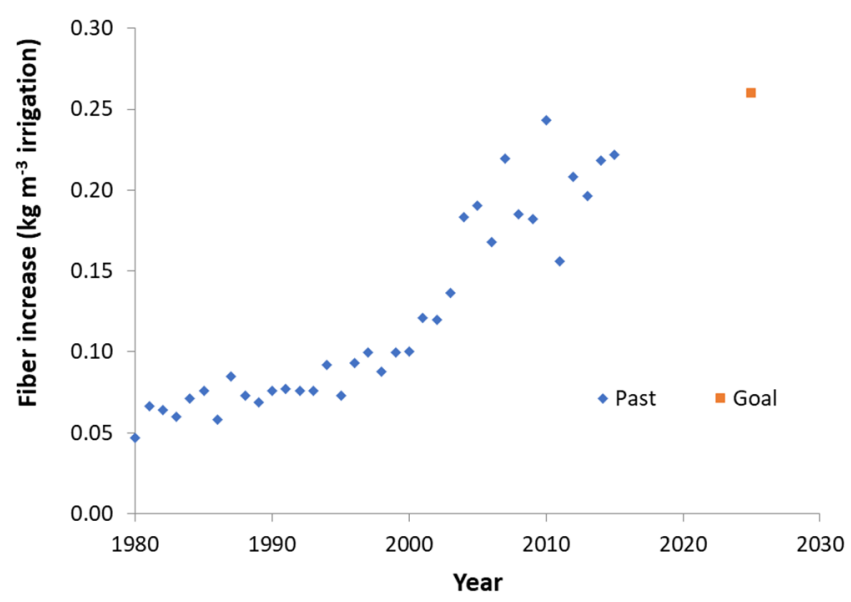

Figure 14. Trends in U.S. ICWP vs. time based on Field to Market (2016) data and the 2025 goal for yield by the American Cotton Producers of the National Cotton Council (NCC, 2018). and technological advances and grower adoption of those advances must continue to meet the stated goal. Harmel et al. (2020) outlined several actions that are needed to improve global water security, and those that could be directly applied to cotton are listed in table 2.

Additional opportunities for improved cotton CWP have also been identified from the studies reviewed in this article. Whenever surface irrigation systems are used, computeraided design for both basin and furrow irrigation is highly recommended. There needs to be an increased use of flow meters and other flow measurement devices to ensure the water a farmer assumes is applied to the field is what is delivered by the irrigation system. The lack of VRI adoption for center pivots is partly due to lack of commercially available tools to manage irrigation zones. Irrigation system manufacturers are adding more tools to their systems that should enable a great number of farmers to adopt VRI technology. It should be noted that Thorp et al. (2020) found VRI will not always be a necessary technology. Such a statement should extend to all water delivery methods, as the ideal method will vary based on water source (e.g., canal versus well), soil conditions, climate, and economic benefits. The increase of new irrigation systems in the SW demonstrates cotton growers will adopt new technologies when there are clear economic benefits. There have been examples of partnerships with the USDA-NRCS to cost share improvements for both irrigation systems and management tools and such programs should be continued and expanded in the future. 
Table 2. Actions to improve global water security from Harmel et al. (2020) that apply to cotton production.

\begin{tabular}{|c|c|c|}
\hline Strategy & Comment & Citations \\
\hline $\begin{array}{l}\text { Increase wastewater } \\
\text { reuse }\end{array}$ & $\begin{array}{l}\text { The availability of wastewater as an irrigation water source will be limited in many areas of } \\
\text { the cotton belt as a majority of cotton is not produced near large population centers. However, } \\
\text { cotton can use marginal quality water sources when available. This is mainly due to greater } \\
\text { tolerance of cotton to irrigation water salinity compared to many other crops. }\end{array}$ & Goyal et al. (1999). \\
\hline $\begin{array}{l}\text { Increase agricultural } \\
\text { resiliency and } \\
\text { efficiency }\end{array}$ & $\begin{array}{l}\text { For some regions, shifting planting dates may allow producers to either better take advantage } \\
\text { of greater rainfall periods or avoid maximum evapotranspiration demand periods. Varieties } \\
\text { with increased drought tolerance will be needed in the future, particularly in areas where aqui- } \\
\text { fers are becoming depleted. Increased crop resiliency will come from improved soil health } \\
\text { (greater water holding capacity) and improved rainfall infiltration when cover crops are used. }\end{array}$ & Ale et al. (2020). \\
\hline Optimize CWP & $\begin{array}{l}\text { Continued adoption of improved irrigation delivery systems. Irrigation scheduling tools need } \\
\text { to be simple and user-friendly to increase their adoption by growers and consultants. For ET } \\
\text { based scheduling methods, robust ways to account for impacts of cotton variety and environ- } \\
\text { mental differences on crop coefficients are needed. }\end{array}$ & $\begin{array}{l}\text { USDA-NRCS (2012b); } \\
\text { Evett et al. (2014); } \\
\text { O’Shaughnessy et al. } \\
\text { (2015). }\end{array}$ \\
\hline $\begin{array}{l}\text { Improve water } \\
\text { resource } \\
\text { infrastructure }\end{array}$ & $\begin{array}{l}\text { In many regions of the eastern U.S., there are opportunities to increase the use of on-farm } \\
\text { ponds to capture rainfall runoff, particularly in the winter months. For cotton fields that are } \\
\text { served by irrigation districts, improving operation and maintenance of the irrigation network } \\
\text { could reduce seepage and operational losses. }\end{array}$ & $\begin{array}{l}\text { Yaeger et al. (2017); } \\
\text { Shahdany et al. (2019; } \\
\text { Barkhordari et al. (2020). }\end{array}$ \\
\hline
\end{tabular}

There are many options for evapotranspiration-based irrigation scheduling tools, and many are available specific to conditions and data available on a state-by-state basis. Efforts should continue to improve the accuracy of these tools and increase their ease of use. Wireless data systems are increasing the adoption of soil water sensors and continued efforts are needed to educate growers on their use. Canopy temperature approaches particularly in the FW and SW, should be reevaluated as new and more affordable sensors become available. The ability of crop simulation models to accurately predict cotton yield responses to irrigation schedules should continue to be used to evaluate irrigation strategies across U.S. cotton regions using long-term weather records. Work to find the most effective methods to combine sensor-based data with simulation models to automate control of irrigation systems should continue.

\section{CONCLUSIONS}

CWP of U.S. Cotton has increased considerably during last 40 years. Several factors contributed to this increase, that often varied by region. Across all regions, improved irrigation delivery systems increased application efficiency and reduced irrigation water use. Improved irrigation scheduling has also resulted in increased CWP particularly with a number of evapotranspiration-based irrigation schedulers that have been made widely available across the U.S. The use of soil water sensors for irrigation scheduling is increasing, as affordable wireless data delivery is making the sensor data easily available to growers. An increase in cotton yields without increased water use can also be attributed to improved cotton genetics and overall improved agronomic management tools. An improved understanding of cotton physiological responses to water stress has also resulted in a knowledge of the critical growth stages to prevent water stress when the irrigation water supply is limited, and it has led to improved cotton growth simulation models to allow accurate simulation of different irrigation strategies.

Given declining water resources and increased climate variability, the increase in CWP must continue. On-farm storage of rainfall runoff and tail water should be increased wherever possible, and the work to consider shallow ground water recharge to expand water storage capacity without sacrificing land area needs to continue. Where center pivots are in use, farmers should give serious consideration to adding variable rate control systems when there is considerable variation in soil water holding capacity, topography, or both in their fields. The increased use of sensors for real-time feedback should also continue, and there may be a time in the near future where we need to reevaluate the use of canopy temperature for irrigation management as the costs of the hardware decline and new ways to deploy thermal sensors are devised. Ultimately, integrating sensor-based data, models, and weather forecasts will lead to very robust irrigation scheduling decisions. There are also indications that genetic gains for cotton will continue, and gene editing could bring additional improvements in cotton productivity without a significant increase in any inputs, including water.

\section{REFERENCES}

Adhikari, P., Ale, S., Bordovsky, J. P., Thorp, K. R., Modala, N. R., Rajan, N., \& Barnes, E. M. (2016). Simulating future climate change impacts on seed cotton yield in the Texas High Plains using the CSM-CROPGRO-Cotton model. Agric. Water Manag., 164, 317-330. https://doi.org/10.1016/j.agwat.2015.10.011

Ale, S., Omani, N., Himanshu, S. K., Bordovsky, J. P., Thorp, K. R., \& Barnes, E. M. (2020). Determining optimum irrigation termination periods for cotton production in the Texas High Plains. Trans. ASABE, 63(1), 105-115. https://doi.org/10.13031/trans. 13483

Allen, R. G., Pereira, L. S., Raes, D., \& Smith, M. (1998). Crop evapotranspiration: Guidelines for computing crop water requirements. FAO Irrigation and Drainage Paper No. 56. Rome Italy: United Nations FAO.

Amosson, S., Nair, S., Guerrero, B., \& Marek, T. (2015). Panhandle Regional Water Plan Task 5 Report: Agricultural water management strategies. In 2016 Panhandle water plan (Vol. II, pp. 55-74). Panhandle Regional Water Planning Group. Retrieved from http://www.panhandlewater.org/Region\%20A\%20Volume\%20I I\%20Appendices.pdf 
Anapalli, S. S., Fisher, D. K., Pinnamaneni, S. R., \& Reddy, K. N. (2020). Quantifying evapotranspiration and crop coefficients for cotton (Gossypium hirsutum L.) using an eddy covariance approach. Agric. Water Manag., 233, 106091. https://doi.org/10.1016/j.agwat.2020.106091

Anapalli, S. S., Fisher, D. K., Reddy, K. N., Krutz, J. L., Pinnamaneni, S. R., \& Sui, R. (2019). Quantifying water and $\mathrm{CO} 2$ fluxes and water use efficiencies across irrigated $\mathrm{C} 3$ and C4 crops in a humid climate. Sci. Total Environ., 663, 338-350. https://doi.org/10.1016/j.scitotenv.2018.12.471

ASABE Standards. (2015). S526.4: Soil and water terminology. St. Joseph, MI: ASABE.

ASCE-EWR. (2005). The ASCE standardized reference evapotranspiration equation. In R. G. Allen, I. A. Walter, R. L. Elliot, T. A. Howell, D. Itenfisu, M. E. Jensen, \& R. L. Snyder (Eds.), Standardization of reference evapotranspiration task committee final report (pp. 1-11). ASCE-EWRI.

Barkhordari, S., Shahadany, S. H., Taghvaeian, S., Firoozfar, A. R., \& Maestre, J. M. (2020). Reducing losses in earthen agricultural water conveyance and distribution systems by employing automatic control systems. Comput. Electron. Agric., 168, 105122. https://doi.org/10.1016/j.compag.2019.105122

Bautista, E., Clemmens, A. J., Strelkoff, T. S., \& Schlegel, J. (2009). Modern analysis of surface irrigation systems with WinSRFR. Agric. Water Manag., 96(7), 1146-1154. https://doi.org/10.1016/j.agwat.2009.03.007

Bellamy, C., Khalilian, A., Farahani, H., Privette, C., \& Henderson, W. (2009). Sensor based soil water \& crop monitoring in cotton production. Proc. Beltwide Cotton Conf. (pp. 383-387). Memphis, TN: National Cotton Council of America.

Bockhold, D., Henggeler, J., Sudduth, K., \& Thompson, A. (2001). Comparison of eight irrigation scheduling tools for soybean and cotton. Proc. Irrig. Assoc. Conf., (pp. 117-123).

Bordovsky, J. P. (2001). Comparison of spray, LEPA, and subsurface drip irrigated cotton. Proc. Beltwide Cotton Conf. 1, pp. 301-304. Memphis, TN: National Cotton Council.

Bordovsky, J. P. (2019). Low-energy precision application (LEPA) irrigation: A forty-year review. Trans. ASABE, 62(5), 13431353. https://doi.org/10.13031/trans.13117

Bordovsky, J. P. (2020). Preplant and early-season cotton irrigation timing with deficit amounts using subsurface drip (SDI) systems in the Texas High Plains. Irrig. Sci. https://doi.org/10.1007/s00271-019-00661-3

Bordovsky, J. P., \& Lyle, W. M. (1998). Cotton irrigation with LEPA and subsurface drip systems on the Southern High Plains. Proc. Beltwide Cotton Conf. (pp. 409-412). Memphis, TN: National Cotton Council.

Bordovsky, J. P., Mustian, J. T., Ritchie, G. L., \& Lewis, K. L. (2015). Cotton irrigation timing with variable seasonal irrigation capacities in the Texas South Plains. Appl. Eng. Agric., 31(6), 883-897. https://doi.org/10.13031/aea.31.10953

Bos, M. G. (1980). Irrigation efficiencies at crop production level. ICID Bull. 29, 18-25, 60.

Campbell, B. T., Boykin, D., Meredith Jr., W. R., \& Abdo, Z. (2014). Chapter 2 - Cotton. In S. Smith, B. Diers, J. Specht, \& B. Carver (Eds.), Yield gains in major U.S. field crops. CSSA Special Publ. 33. Madison, WI: ASA, CSSA, SSSA.

Clemmens, A. J. (1992). Feedback control of basin-irrigation system. J. Irrig. Drain. Eng., 118(3), 480-496. https://doi.org/10.1061/(ASCE)0733-9437(1992)118:3(480)

Colaizzi, P. D., Agam, N., Tolk, J. A., Evett, S. R., Howell Sr., T. A., O'Shaughnessy, S. A.,... Anderson, M. C. (2016). Advances in a two-source energy balance model: Partitioning of evaporation and transpiration for cotton. Trans. ASABE, 59(1), 181-197. https://doi.org/10.13031/trans.59.11215
Colaizzi, P. D., Barnes, E. M., Clarke, T. R., Choi, C. Y., \& Waller, P. M. (2003). Estimating soil moisture under low frequency surface irrigation using crop water stress index. J. Irrig. Drain. Eng., 129(1), 27-35. https://doi.org/10.1061/(ASCE)07339437(2003)129:1(27)

Colaizzi, P. D., Evett, S. R., Howell Sr., T. A., \& Baumhardt, R. L. (2010). Crop production comparison with spray, LEPA, and subsurface drip irrigation in the Texas High Plains. In M. Dukes (Ed.), Proc. 5th National Decennial Irrigation Conf. St. Joseph, MI: ASABE. https://doi.org/10.13031/2013.35818

Colaizzi, P. D., Gowda, P. H., Marek, T. H., \& Porter, D. O. (2009). Irrigation in the Texas High Plains: A brief history and potential reductions in demand. Irrig. Drain., 58(3), 257-274. https://doi.org/10.1002/ird.418

CTIC. (2020). Crop residue management survey. Conservation Technology Information Center. Retrieved from https://www.ctic.org/CRM

Datta, S., Taghvaeian, S., Ochsner, T. E., Moriasi, D., Gowda, P., \& Steiner, J. L. (2018). Performance assessment of five different soil moisture sensors under irrigated field conditions in Oklahoma. Sensors, 18(11), 3786. https://doi.org/10.3390/s18113786

Daystar, J. S., Barnes, E., Hake, K., \& Kurtz, R. (2017). Sustainability trends and natural resource use in US cotton production. BioResour., 12(1), 362-392. https://doi.org/10.15376/biores.12.1.362-392

DeJonge, K. C., \& Thorp, K. R. (2017). Implementing standardized reference evapotranspiration and dual crop coefficient approach in the DSSAT cropping system model. Trans. ASABE, 60(6), 1965-1981. https://doi.org/10.13031/trans.12321

Delta Plastics. (2019). Pipe planner. Retrieved from https://www.pipeplanner.com

Dukes, M. D., \& Scholberg, J. M. (2004). Soil moisture controlled subsurface drip irrigation on sandy soils. Appl. Eng. Agric., 21(1), 89-101. https://doi.org/10.13031/2013.17916

EIA. (2018). U.S. natural gas wellhead price. Independent Statistics \& Analysis, U.S. Energy Information Administration. Retrieved from https://www.eia.gov/dnav/ng/hist/n9190us3a.htm

Evans, R. G., LaRue, J., Stone, K. C., \& King, B. A. (2013). Adoption of site-specific variable rate sprinkler irrigation systems. Irrig. Sci., 31(4), 871-887. https://doi.org/10.1007/s00271-012-0365-x

Evett, S. R., \& Parkin, G. W. (2005). Advances in soil water content sensing: The continuing maturation of technology and theory. Vadose Zone J., 4(4), 986-991. https://doi.org/10.2136/vzj2005.0099

Evett, S. R., Heng, L. K., Moutonnet, P., \& Nguyen, M. L. (2008). Field estimation of soil water content: a practical guide to methods, instrumentation, and sensor technology. IAEA-TCS30. Vienna Austria: International Atomic Energy Agency.

Evett, S. R., Marek, G. W., Colaizzi, P. D., Brauer, D. K., \& O'Shaughnessy, S. A. (2019). Corn and sorghum ET, E, yield, and CWP as affected by irrigation application method: SDI versus mid-elevation spray irrigation. Trans. ASABE, 62(5), 1377-1393. https://doi.org/10.13031/trans.13314

Evett, S. R., O'Shaughnessy, S. A., \& Peters, R. T. (2014). Irrigation scheduling and supervisory control data acquisition system for moving and static irrigation systems. U.S. Patent No. US 8,924,031 B1.

Evett, S. R., Tolk, J. A., \& Howell, T. A. (2006). Soil profile water content determination: Sensor accuracy, axial response, calibration, temperature dependence, and precision. Vadose Zone J., 5(3), 894-907. https://doi.org/10.2136/vzj2005.0149

Farahani, H. J., Oweis, T. Y., \& Izzi, G. (2008). Crop coefficient for drip-irrigated cotton in a Mediterranean environment. Irrig. Sci., 26(5), 375-383. https://doi.org/10.1007/s00271-007-0101-0 
Fares, A., \& Alva, A. K. (2000). Evaluation of capacitance probes for optimal irrigation of citrus through soil moisture monitoring in an entisol profile. Irrig. Sci., 19(2), 57-64. https://doi.org/10.1007/s002710050001

Farg, E., Arafat, S. M., Abd El-Wahed, M. S., \& El-Gindy, A. M. (2012). Estimation of evapotranspiration ETc and crop coefficient Kc of wheat, in south Nile Delta of Egypt using integrated FAO-56 approach and remote sensing data. Egyptian J. Remote Sensing Space Sci., 15(1), 83-89. https://doi.org/10.1016/j.ejrs.2012.02.001

Field to Market: The Alliance for Sustainable Agriculture. (2016). Environmental and socioeconomic indicators for measuring outcomes of on farm agricultural production in the United States (3rd. ed.).

Fisher, D. K. (2012). Simple weighing lysimeters for measuring evapotranspiration and developing crop coefficients. Int. J. Agric. Biol. Eng., 5(3), 35-43.

Fisher, D. K., Woodruff, L. K., Anapalli, S. S., \& Pinnamaneni, S. R. (2018). Open-source wireless cloud-connected agricultural sensor network. J. Sensor Actuator Networks, 7(4), 47. https://doi.org/10.3390/jsan7040047

Fisher, D. K., Fletcher, R. S., \& Anapalli, S. S. (2020). Evolving open-source technologies offer options for remote sensing and monitoring in agriculture. Adv. Internet of Things, 10, 1-10. https://doi.org/10.4236/ait.2020.101001

Frisvold, G., Sanchez, C., Gollehon, N., Megdal, S. B., \& Brown, P. (2018). Evaluating gravity-flow irrigation with lessons from Yuma, Arizona, USA. Sustainability, 10(5), 1548. https://doi.org/10.3390/su10051548

Gardner, B. R., Nielsen, D. C., \& Shock, C. C. (1992a). Infrared thermometry and the crop water stress index. I. History, theory, and baselines. J. Prod. Agric., 5(4), 462-466. https://doi.org/10.2134/jpa1992.0462

Gardner, B. R., Nielsen, D. C., \& Shock, C. C. (1992b). Infrared thermometry and the crop water stress index. II. Sampling procedures and interpretation. J. Prod. Agric., 5(4), 466-475. https://doi.org/10.2134/jpa1992.0466

Geisseler, D., \& Horwath, W. R. (2016). Cotton production in California. Davis: University of California. Retrieved from https://apps1.cdfa.ca.gov/FertilizerResearch/docs/Cotton_Produc tion_CA.pdf

Goyal, S. S., Sharma, S. K., Rains, D. W., \& Lauchli, A. (1999). Long-term reuse of drainage waters of varying salinities for crop irrigation in a cotton-safflower rotation system in the San Joaquin Valley of California: A nine year study: I. Cotton (Gossypium hirsutum L.). J. Crop Prod., 2(2), 181-213. https://doi.org/10.1300/J144v02n02_07

Grant, T. J., Leib, B. G., Duncan, H. A., Main, C. L., \& Verbree, D. A. (2017a). A deficit irrigation trial in differing soils used to evaluate cotton irrigation scheduling for the Mid-South. $J$. Cotton Sci., 21(4), 265-274.

Grant, T. J., Leib, B. G., Savoy, H. J., Verbree, D. A., \& Haghverdi, A. (2017b). Cotton response to irrigation and nitrogen source in differing Mid-South soils. Agron. J., 109(6), 2537-2544. https://doi.org/10.2134/agronj2017.03.0147

Gutierrez, J., Villa-Medina, J. F., Nieto-Garibay, A., \& PortaGandara, M. A. (2013). Automated irrigation system using a wireless sensor network and GPRS module. IEEE Trans. Instrum. Meas., 63(1), 166-176. https://doi.org/10.1109/TIM.2013.2276487

Gwathmey, C. O., Leib, B. G., \& Main, C. L. (2011). Lint yield and crop maturity responses to irrigation in a short-season environment. J. Cotton Sci., 15(1), 1-10.

Haghverdi, A., \& Leib, B. G. (2018). Site specific irrigation systems. In Precision agriculture for sustainability. Burleigh Dodds Science Publ.
Haghverdi, A., Leib, B. G., Washington-Allen, R. A., Buschermohle, M. J., \& Ayers, P. D. (2016). Studying uniform and variable rate center pivot irrigation strategies with the aid of site-specific water production functions. Comput. Electron. Agric., 123, 327-340. https://doi.org/10.1016/j.compag.2016.03.010

Haghverdi, A., Leib, B., Washington-Allen, R., Wright, W. C., Ghodsi, S., Grant, T.,... Vanchiasong, P. (2019). Studying crop yield response to supplemental irrigation and the spatial heterogeneity of soil physical attributes in a humid region. Agric., 9(2), 43. https://doi.org/10.3390/agriculture9020043

Haghverdi, A., Washington-Allen, R. A., \& Leib, B. G. (2018). Prediction of cotton lint yield from phenology of crop indices using artificial neural networks. Comput. Electron. Agric., 152, 186-197. https://doi.org/10.1016/j.compag.2018.07.021

Hardee, D. D., \& Harris, F. A. (2003). Eradicating the boll weevil (Coleoptera: Curculionidae): A clash between a highly successful insect, good scientific achievement, and differing agricultural philosophies. American Entomologist, 49(2), 82-97. https://doi.org/10.1093/ae/49.2.82

Harmel, R. D., Chaubey, I., Ale, S., Nejadhashemi, A. P., Irmak, S., DeJonge, K. C.,... Mani, I. (2020). Perspectives on global water security. Trans. ASABE, 63(1), 69-80.

https://doi.org/10.13031/trans.13524

Haule, J., \& Michael, K. (2014). Deployment of wireless sensor networks (WSN) in automated irrigation management and scheduling systems: A review. Proc. 2nd Pan African Int. Conf. on Science, Computing and Telecommunications (PACT 2014), (pp. 86-91). https://doi.org/10.1109/SCAT.2014.7055144

Henggeler, J., Robinson, P. M., \& Scherer, T. F. (2010). Irrigation scheduling programs of the last ten years. ASABE Paper No. IRR10-9842. St. Joseph, MI: ASABE.

Himanshu, S. K., Ale, S., Bordovsky, J., \& Darapuneni, M. (2019). Evaluation of crop-growth-stage-based deficit irrigation strategies for cotton production in the Southern High Plains. Agric. Water Manag., 225, 105782. https://doi.org/10.1016/j.agwat.2019.105782

Holloway-Phillips, M. M., Peng, W., Smith, D., \& Terhorst, A. (2008). Adaptive scheduling in deficit irrigation: A model-data fusion approach. WIT Trans. Eco. Environ., 112, 187-200. https://doi.org/10.2495/SI080191

Holman, E. M., \& Oosterhuis, D. M. (1999). Cotton photosynthesis and carbon partitioning in response to floral bud loss due to insect damage. Crop Sci., 39(5), 1347-1351. https://doi.org/10.2135/cropsci1999.3951347x

Howell, T. A. (2001). Enhancing water use efficiency in irrigated agriculture. Agron. J., 93(2), 281-289. https://doi.org/10.2134/agronj2001.932281x

Howell, T. A. (2006). Water losses associated with center pivot nozzle packages. Proc. Central Plains Irrigation Conf., (pp. 1224). Retrieved from https://www.ksre.kstate.edu/irrigate/oow/p06/Howell06.pdf

Howell, T. A., \& Lamm F., R. (2007). Is irrigation real or am I imagining it? Proc. 28th Annual Int. Irrigation Assoc. Tech. Conf. Falls Church, VA: Irrigation Association.

Howell, T. A., \& Phene, C. J. (1983). Distribution of irrigation water from a low pressure, lateral-moving irrigation system. Trans. ASAE, 26(5), 1422-1429. https://doi.org/10.13031/2013.34144

Howell, T. A., Evett, S. R., Tolk, J. A., \& Schneider, A. D. (2004). Evapotranspiration of full-, deficit-irrigated, and dryland cotton on the Northern Texas High Plains. J. Irrig. Drain. Eng., 130(4), 277-285. https://doi.org/10.1061/(ASCE)0733-

9437(2004)130:4(277) 
Howell, T. A., Schneider, A. D., Dusek, D. A., Marek, T. H., \& Steiner, J. L. (1995). Calibration and scale performance of Bushland weighing lysimeters. Trans. ASAE, 38(4), 1019-1024. https://doi.org/10.13031/2013.27918

HPWD. (2019). Annual report, High Plains Underground Water Conservation District No. 1. HPWD. Retrieved from http://www.hpwd.org/reports/

Hunsaker, D. J., Barnes, E. M., Clarke, T. R., Fitzgerald, G. J., \& Pinter Jr., P. J. (2005). Cotton irrigation scheduling using remotely sensed and FAO-56 basal crop coefficients. Trans. ASAE, 48(4), 1395-1407. https://doi.org/10.13031/2013.19197

Hunsaker, D. J., Clemmens, A. J., \& Fangmeier, D. D. (1998). Cotton response to high frequency surface irrigation. Agric. Water Manag., 37(1), 55-74. https://doi.org/10.1016/S03783774(98)00036-5

Hunsaker, D. J., French, A. N., Waller, P. M., Bautista, E., Thorp, K. R., Bronson, K. F., \& Andrade-Sanchez, P. (2015). Comparison of traditional and ET-based irrigation scheduling of surface-irrigated cotton in the arid southwestern USA. Agric. Water Manag., 159, 209-224. https://doi.org/10.1016/j.agwat.2015.06.016

Idso, S. B. (1982). Non-water-stressed baselines: A key to measuring and interpreting plant water stress. Agric. Meteorol., 27(1), 59-70. https://doi.org/10.1016/0002-1571(82)90020-6

Irmak, S., Odhiambo, L. O., Specht, J. E., \& Djaman, K. (2013). Hourly and daily single and basal evapotranspiration crop coefficients as a function of growing degree days, days after emergence, leaf area index, fractional green canopy cover, and plant phenology for soybean. Trans. ASABE, 56(5), 1785-1803. https://doi.org/10.13031/trans.56.10219

Jackson, R. D. (1982). Canopy temperature and crop water stress. In D. Hillel (Ed.), Advances in irrigation (Vol. 1, pp. 43-85). Cambridge, MA: Elsevier. https://doi.org/10.1016/B978-0-12024301-3.50009-5

Jackson, R. D., Idso, S. B., Reginato, R. J., \& Pinter Jr., P. J. (1981). Canopy temperature as a crop water stress indicator. Water Resour. Res., 17(4), 1133-1138. https://doi.org/10.1029/WR017i004p01133

Jones, H. G. (2006). Irrigation scheduling-comparison of soil, plant and atmosphere monitoring approaches. Proc. 5th Int. Symp. on Irrigation of Horticultural Crops (pp. 391-403). International Society for Horticultural Science (ISHS). https://doi.org/10.17660/ActaHortic.2008.792.46

Kebede, H., Fisher, D. K., Sui, R., \& Reddy, K. N. (2014). Irrigation methods and scheduling in the Delta region of Mississippi: Current status and strategies to improve irrigation efficiency. American J. Plant Sci., 5(20), 2917. https://doi.org/10.4236/ajps.2014.520307

Kisekka, I., Oker, T., Nguyen, G., Aguilar, J., \& Rogers, D. (2017). Revisiting precision mobile drip irrigation under limited water. Irrig. Sci., 35(6), 483-500. https://doi.org/10.1007/s00271-0170555-7

Ko, J., Piccinni, G., Marek, T., \& Howell, T. (2009). Determination of growth-stage-specific crop coefficients $(\mathrm{Kc})$ of cotton and wheat. Agric. Water Manag., 96(12), 1691-1697. https://doi.org/10.1016/j.agwat.2009.06.023

Krutz, L. J. (2013). Improving furrow irrigation efficiency: Annual Report. Mississippi Soybean Promotion Board. Retrieved from http://mssoy.org/wp-content/uploads/2014/05/54-2013-ANNREP-FINAL.pdf

Lamm, F. R. (2009). Managing the challenges of subsurface drip irrigation. Proc. Irrigation Association Technical Conf. Falls Church, VA: Irrigation Association. Retrieved from https://www.ksre.kstate.edu/sdi/reports/2009/ia/FRLUnique09IA.pdf
Lamm, F. R. (2016). Cotton, tomato, corn, and onion production with subsurface drip irrigation: A review. Trans. ASABE, 59(1), 263-278. https://doi.org/10.13031/trans.59.11231

Lamm, F. R., \& Rogers, D. H. (2015). The importance of irrigation scheduling for marginal capacity systems growing corn. Appl. Eng. Agric., 31(2), 261-265. https://doi.org/10.13031/aea.31.10966

Lamm, F. R., Bordovsky, J. P., \& Howell Sr., T. A. (2019). A review of in-canopy and near-canopy sprinkler irrigation concepts. Trans. ASABE, 62(5), 1355-1364. https://doi.org/10.13031/trans.13229

Lamm, F. R., Bordovsky, J. P., Schwankl, L. J., Grabow, G. L., Enciso-Medina, J., Peters, R. T.,... Porter, D. O. (2012). Subsurface drip irrigation: Status of the technology in 2010. Trans. ASABE, 55(2), 483-491. https://doi.org/10.13031/2013.41387

Leib, B. G., Grant, T., \& Raper, T. B. (2018). The basics of cotton irrigation in Tennessee. W809-C. Knoxville: University of Tennessee - Extension.

Leib, B. G., Jabro, J. D., \& Matthews, G. R. (2003). Field evaluation and performance comparison of soil moisture sensors. Soil Sci., 168(6), 396-408. https://doi.org/10.1097/01.ss.0000075285.87447.86

Leib, B. G., Payero, J., Pringle, L., Bordovsky, L., Porter, L., \& Barnes, E. M. (2015). Placement and interpretation of soil moisture sensors for irrigated cotton production in humid regions. Cary, NC: Cotton Inc. Retrieved from https://cottoncultivated.cottoninc.com/wpcontent/uploads/2015/12/Soil-Moisture-Sensors.pdf

Liu, S. M., Constable, G. A., Reid, P. E., Stiller, W. N., \& Cullis, B. R. (2013). The interaction between breeding and crop management in improved cotton yield. Field Crops Res., 148, 49-60. https://doi.org/10.1016/j.fcr.2013.04.006

Luttrell, R. G., Teague, T. G., \& Brewer, M. J. (2015). Cotton insect pest management. In D. D. Fang, \& R. G. Percy (Eds.), Cotton (2nd. ed., pp. 509-546). Madison, WI: ASA, CSSA, SSSA. https://doi.org/10.2134/agronmonogr57.2014.0072

Lyle, W. M., \& Bordovsky, J. P. (1983). LEPA irrigation system evaluation. Trans. ASAE, 26(3), 776-781. https://doi.org/10.13031/2013.34022

Mahan, J. R., Burke, J. J., Wanjura, D. F., \& Upchurch, D. R. (2005). Determination of temperature and time thresholds for BIOTIC irrigation of peanut on the Southern High Plains of Texas. Irrig. Sci., 23(4), 145-152. https://doi.org/10.1007/s00271-005-0102-9

Marek, G. W., Evett, S. R., Gowda, P. H., Howell, T. A., Copeland, K. S., \& Louis Baumhardt, R. (2014). Post-processing techniques for reducing errors in weighing lysimeter evapotranspiration (ET) datasets. Trans. ASABE, 57(2), 499-515. https://doi.org/10.13031/trans.57.10433

Marek, T. H., Schneider, A. D., Howell, T. A., \& Ebeling, L. L. (1988). Design and construction of large weighing monolithic lysimeters. Trans. ASAE, 31(2), 477-484. https://doi.org/10.13031/2013.30734

Marek, T., Porter, D., Gowda, P., Howell, T., \& Moorhead, J. (2010). Assessment of Texas Evapotranspiration (ET) Networks. Final Project Report of TWDB Contract No. 0903580904. Austin: Texas Water Development Board. Retrieved from https://www.twdb.texas.gov/publications/reports/contracted_rep orts/doc/0903580904_evapotranspiration.pdf.

Martin, E. C., \& Slack, D. C. (2005). AZSCHED V2.0: Climatebased irrigation scheduling in Arizona. Proc. Int. Irrigation Technical Conf. Falls Church, VA: Irrigation Assoc. 
Masasi, B., Taghvaeian, S., Boman, R., \& Datta, S. (2019). Impacts of irrigation termination date on cotton yield and irrigation requirement. Agric., 9(2), 39. https://doi.org/10.3390/agriculture9020039

Massey, J. (2010). Water-conserving irrigation systems for furrow and flood irrigated crops in the Mississippi Delta. Final Report. Mississippi Water Resources Research Institute (MWRRI).

Massey, J. (2011). Water and energy conservation practices for Mississippi rice production. Retrieved from http://www.mississippi-crops.com/wpcontent/uploads/2011/11/Irrigation-Methods-and-Ways-to-SaveMoney-Compatibility-Mode.pdf

McDougall, W. M., Henry, C. G., Reba, M. L., \& Carman, D. K. (2014). A pump monitoring approach to irrigation pumping plant testing. ASABE Paper No. 141928167. St. Joseph, MI: ASABE.

McGuire, V. L. (2017). Data used to map water-level changes in the High Plains aquifer, predevelopment (about 422 1950) to 2015 and 2013 to 2015: U.S. Geological Survey data release. USGS. Retrieved from https://doi.org/10.1130/abs/2017NE-290528

Meeks, C. D., Snider, J. L., Porter, W. M., Vellidis, G., Hawkins, G., \& Rowland, D. (2017). Assessing the utility of primed acclimation for improving water savings in cotton using a sensor-based irrigation scheduling system. Crop Sci., 57(4), 2117-2129. https://doi.org/10.2135/cropsci2016.10.0907

Meredith, W. R., \& Bridge, R. R. (1984). Genetic contributions to yield changes in upland cotton. In W. R. Fehr (Ed.), Genetic contributions to yield gains of five major crop plants (pp. 7587). Madison, WI: ASA, CSSA. https://doi.org/10.2135/cssaspecpub7.c4

Midgley, C. (2019). Precision irrigation scheduling: We have a problem. Retrieved from https://www.precisionag.com/in-fieldtechnologies/irrigation/precision-irrigation-scheduling-we-havea-problem/.

Miranda, F. R., Yoder, R. E., Wilkerson, J. B., \& Odhiambo, L. O. (2005). An autonomous controller for site-specific management of fixed irrigation systems. Comput. Electron. Agric., 48(3), 183-197. https://doi.org/10.1016/j.compag.2005.04.003

Moran, M. S., Clarke, T. R., Inoue, Y., \& Vidal, A. (1994). Estimating crop water deficit using the relation between surfaceair temperature and spectral vegetation index. Remote Sens. Environ., 49(3), 246-263. https://doi.org/10.1016/00344257(94)90020-5

Morison, J. I. L., Baker, N. R., Mullineaux, P. M., \& Davies, W. J. (2008). Improving water use in crop production. Philosophical Trans. Royal Soc. B: Biol. Sci., 363(1491), 639-658. https://doi.org/10.1098/rstb.2007.2175

NCC. (2018). U.S. Cotton ten year sustainability goals - Pathways to progress. National Cotton Council of America, Cotton USA, Cotton Inc. Retrieved from https://cottontoday.cottoninc.com/wpcontent/uploads/2018/02/Cotton_Sustainability_2018_low.pdf

Negri, D. H., \& Brooks, D. H. (1990). Determinants of irrigation technology choice. Western J. Agric. Econ., 15, 213-223.

O'Shaughnessy, S. A., \& Colaizzi, P. D. (2017). Performance of precision mobile drip irrigation in the Texas High Plains Region. Agron., 7(4), 68. https://doi.org/10.3390/agronomy7040068

O'Shaughnessy, S. A., \& Evett, S. R. (2010). Canopy temperature based system effectively schedules and controls center pivot irrigation of cotton. Agric. Water Manag., 97(9), 1310-1316. https://doi.org/10.1016/j.agwat.2010.03.012

O'Shaughnessy, S. A., \& Sui, R. (2018). Advanced tools for irrigation scheduling. In G. Chen (Ed.), Advances in agricultural machinery and technologies (pp. 263-288). Boca Raton, FL: CRC Press. https://doi.org/10.1201/9781351132398-11
O’Shaughnessy, S. A., Evett, S. R., \& Colaizzi, P. D. (2015). Dynamic prescription maps for site-specific variable rate irrigation of cotton. Agric. Water Manag., 159, 123-138. https://doi.org/10.1016/j.agwat.2015.06.001

O’Shaughnessy, S. A., Evett, S. R., Colaizzi, P. D., \& Howell, T. A. (2011). Using radiation thermography and thermometry to evaluate crop water stress in soybean and cotton. Agric. Water Manag., 98(10), 1523-1535. https://doi.org/10.1016/j.agwat.2011.05.005

O’Shaughnessy, S. A., Evett, S. R., Colaizzi, P. D., Andrade, M. A., Marek, T. H., Heeren, D. M.,... LaRue, J. L. (2019). Identifying advantages and disadvantages of variable rate irrigation: An updated review. Appl. Eng. Agric., 35(6), 837-852. https://doi.org/10.13031/aea.13128

O’Shaughnessy, S. A., Urrego, Y. F., Evett, S. R., Colaizzi, P. D., \& Howell, T. A. (2013). Assessing application uniformity of a variable rate irrigation system in a windy location. Appl. Eng. Agric., 29(4), 497-510. https://doi.org/http://dx.doi.org/10.13031/aea.29.9931

Payero, J. O., \& Irmak, S. (2013). Daily energy fluxes, evapotranspiration and crop coefficient of soybean. Agric. Water Manag., 129, 31-43. https://doi.org/10.1016/j.agwat.2013.06.018

Payero, J. O., Mirzakhani-Nafchi, A., Khalilian, A., Qiao, X., \& Davis, R. (2017). Development of a low-cost Internet-of-Things (IoT) system for monitoring soil water potential using Watermark 200SS sensors. Adv. Internet Things, 7(3), 71-86. https://doi.org/10.4236/ait.2017.73005

Perry, C., \& Pocknee, S. (2003). Development of a variable-rate pivot irrigation control system. Proc. Georgia Water Resources Conf.

Perry, C., Pocknee, S., Hansen, O., Kvien, C., Vellidis, G., \& Hart, E. (2002). Development and testing of a variable rate irrigation control system. ASAE Paper No. 02-2290. St. Joseph, MI: ASAE.

Peters, R. T., \& Evett, S. R. (2008). Automation of a center pivot using the temperature-time-threshold method of irrigation scheduling. J. Irrig. Drain. Eng., 134(3), 286-291. https://doi.org/10.1061/(ASCE)0733-9437(2008)134:3(286)

Phene, C. J., Allee, C. P., \& Pierro, J. D. (1989). Soil matric potential sensor measurements in real-time irrigation scheduling. Agric. Water Manag., 16(3), 173-185. https://doi.org/10.1016/0378-3774(89)90001-2

Phene, C. J., Howell, T. A., \& Sikorski, M. D. (1985). A traveling trickle irrigation system. In D. Hillel (Ed.), Advances in irrigation (Vol. 3, pp. 1-49). Cambridge, MA: Elsevier. https://doi.org/10.1016/B978-0-12-024303-7.50006-6

Radin, J. W., Reaves, L. L., Mauney, J. R., \& French, O. F. (1992). Yield enhancement in cotton by frequent irrigations during fruiting. Agron.. J., 84(4), 551-557. https://doi.org/10.2134/agronj1992.00021962008400040002x

Rawlins, S. L., Hoffman, G. W., \& Merrill, S. D. (1974). Traveling trickle system. Proc. Int. Drip Irrigation Cong., (pp. 184-187).

Ray, R. (2013). MSU pushes RISER Plan for efficient crop irrigation. Mississippi Agricultural News, Mississippi Agricultural and Forestry Experiment Station, Mississippi State University.

Reginato, R. J. (1983). Field quantification of crop water stress. Trans. ASAE, 26(3), 772-775. https://doi.org/10.13031/2013.34021

Schneider, A. D., \& Howell, T. (2000). Surface runoff due to LEPA and spray irrigation of a slowly permeable soil. Trans. ASAE, 43(5), 1089-1095. https://doi.org/10.13031/2013.3001 
Schwartz, R. C., Evett, S. R., Anderson, S. K., \& Anderson, D. J. (2016). Evaluation of a direct-coupled time-domain reflectometry for determination of soil water content and bulk electrical conductivity. Vadose Zone J., 15(1). https://doi.org/10.2136/vzj2015.08.0115

Seyfried, M. S., \& Murdock, M. D. (2001). Response of a new soil water sensor to variable soil, water content, and temperature. SSSAJ, 65(1), 28-34. https://doi.org/10.2136/sssaj2001.65128x

Shahdany, S. H., Taghvaeian, S., Maestre, J. M., \& Firoozfar, A. R. (2019). Developing a centralized automatic control system to increase flexibility of water delivery within predictable and unpredictable irrigation water demands. Comput. Electron. Agric., 163, 104862. https://doi.org/10.1016/j.compag.2019.104862

Smith, R. J., Raine, S. R., \& Minkevich, J. (2005). Irrigation application efficiency and deep drainage potential under surface irrigated cotton. Agric. Water Manag., 71(2), 117-130. https://doi.org/10.1016/j.agwat.2004.07.008

Snipes, C. E., Nichols, S. P., Poston, D. H., Walker, T. W., Evans, L. P., \& Robinson, H. R. (2005). Current agricultural practices of the Mississippi Delta. Mississippi Agric. Forestry Exp. Stn. Bull. 1143.

Soulis, K. X., Elmaloglou, S., \& Dercas, N. (2015). Investigating the effects of soil moisture sensors positioning and accuracy on soil moisture based drip irrigation scheduling systems. Agric. Water Manag., 148, 258-268. https://doi.org/10.1016/j.agwat.2014.10.015

Steger, A. J., Silvertooth, J. C., \& Brown, P. W. (1998). Upland cotton growth and yield response to timing the initial postplant irrigation. Agron. J., 90(4), 455-461. https://doi.org/10.2134/agronj1998.00021962009000040002x

Straatmann, Z., Stevens, G., Vories, E., Guinan, P., Travlos, J., \& Rhine, M. (2018). Measuring short-crop reference evapotranspiration in a humid region using electronic atmometers. Agric. Water Manag., 195, 180-186. https://doi.org/10.1016/j.agwat.2017.10.007

Sui, R. (2018). Irrigation scheduling using soil moisture sensors. $J$. Agric Sci., 10(1). https://doi.org/10.5539/jas.v10n1p1

Sui, R., Fisher, D. K., \& Barnes, E. M. (2012). Soil moisture and plant canopy temperature sensing for irrigation application in cotton. J. Agric Sci., 4(12). https://doi.org/10.5539/jas.v4n12p93

Sui, R., Pringle, H. C., \& Barnes, E. M. (2019). Soil moisture sensor test with Mississippi Delta soils. Trans. ASABE, 62(2), 363-370. https://doi.org/10.13031/trans.12886

Taghvaeian, S., Neale, C. M., \& Santos, C. (2012). Two different remote sensing techniques for monitoring crop coefficient and water requirement of cotton. Remote Sensing Hydrol., 352, 8992.

Tanner, C. B. (1963). Plant temperatures. Agron. J., 55(2), 210-211. https://doi.org/10.2134/agronj1963.00021962005500020043x

Thomson, S., Fisher, D., Sassenrath, G., Freeland, T., \& Pringle, L. (2002). Use of granular-matrix sensors, models, and evapotranspiration measuring devices for monitoring cotton water use and soil water status in the Mississippi Delta. Proc. National Cotton Council Beltwide Cotton Conf. Memphis, TN: NCC.

Thorp, K. R. (2020). Long-term simulations of site-specific irrigation management for Arizona cotton production. Irrig. Sci., 38(1), 49-64. https://doi.org/10.1007/s00271-019-00650-6

Thorp, K. R., Barnes, E. M., Hunsaker, D. J., Kimball, B. A., White, J. W., Nazareth, V. J., \& Hoogenboom, G. (2014). Evaluation of CSM-CROPGRO-cotton for simulating effects of management and climate change on cotton growth and evapotranspiration in an arid environment. Trans. ASABE, 57(6), 1627-1642. https://doi.org/10.13031/trans.57.10612
Thorp, K. R., Elshikha, D. E., \& Andrade-Sanchez, P. (2020). Irrigation management outcomes using increasingly complex geospatial technologies. ASABE Paper No. IRR20-20-004. St. Joseph, MI: ASABE.

Thorp, K. R., Hunsaker, D. J., Bronson, K. F., Andrade-Sanchez, P., \& Barnes, E. M. (2017). Cotton irrigation scheduling using a crop growth model and FAO-56 methods: Field and simulation studies. Trans. ASABE, 60(6), 2023-2039.

https://doi.org/10.13031/trans.12323

Thorp, K. R., Marek, G. W., DeJonge, K. C., Evett, S. R., \& Lascano, R. J. (2019). Novel methodology to evaluate and compare evapotranspiration algorithms in an agroecosystem model. Environ. Model. Softw., 119, 214-227. https://doi.org/10.1016/j.envsoft.2019.06.007

Thorp, K. R., Thompson, A. L., Harders, S. J., French, A. N., \& Ward, R. W. (2018). High-throughput phenotyping of crop water use efficiency via multispectral drone imagery and a daily soil water balance model. Remote Sensing, 10(11), 1682. https://doi.org/10.3390/rs10111682

Tronstad, R. E., Silvertooth, J., \& Husman, S. H. (2003). Irrigation termination of cotton: An economic analysis of yield, quality, and market factors. J. Cotton Sci., 7(3), 86-94.

Unruh, B. L., \& Silvertooth, J. C. (1997). Planting and irrigation termination timing effects on the yield of upland and pima cotton. J. Prod. Agric., 10(1), 74-79. https://doi.org/10.2134/jpa1997.0074

Upchurch, D. R., Wanjura, D. F., Burke, J. J., \& Mahan, J. R. (1996). Biologically-identified optimal temperature interactive console (BIOTIC) for managing irrigation. U.S. Patent $5,539,637$.

USDA-NASS. (1994). Farm and Ranch Irrigation Survey (1994), 1992 Census of Agriculture, AC92-RS-1. Washington, DC: USDA-NASS. Retrieved from http://agcensus.mannlib.cornell.edu/AgCensus/getVolumeTwoP art.do? volnum $=3$ \&year $=1992$ \&part $\mathrm{id}=1039$ \& number $=3 \&$ title $=$ 1994\%20Farm\%20and\%20Ranch\%20Irrigation\%20Survey

USDA-NASS. (1999). Farm and Ranch Irrigation Survey (1998), Vol. 3, Special Studies-Part 1 of the 1997 Census of Agriculture, AC97-SP-1. Washington, DC: USDA-NASS. Retrieved from http://agcensus.mannlib.cornell.edu/AgCensus/getVolumeTwoP art.do? volnum=3\&year=1997\&part id=964\&number=3\&title= Farm\%20and\%20Ranch\%20Irrigation\%20Survey

USDA-NASS. (2004). Farm and Ranch Irrigation Survey (2003), Vol. 3, Special Studies Part 1 of the 2002 Census of Agriculture, AC-02-SS-1. Washington, DC: USDA-NASS. Retrieved from http://usda.mannlib.cornell.edu/usda/AgCensusImages/2002/02/ 06/Complete\%20Report.pdf

USDA-NASS. (2010). Farm and Ranch Irrigation Survey (2008), Vol. 3, Special Studies Part 1 of the 2007 Census of Agriculture, AC-07-SS-1. Washington, DC: USDA-NASS. Retrieved from https://www.nass.usda.gov/Publications/AgCensus/2007/Online Highlights/Farm_and_Ranch_Irrigation_Survey/fris08.pdf

USDA-NASS. (2014). Farm and Ranch Irrigation Survey (2013), Vol. 3, Special Studies Part 1 of the 2012 Census of Agriculture, AC-12-SS-1. Washington, DC: USDA-NASS. Retrieved from https://www.nass.usda.gov/Publications/AgCensus/2012/Online Resources/Farm_and_Ranch_Irrigation_Survey/fris13.pdf USDA-NASS. (2019). $201 \overline{1} 8$ Irrigation and Water Management Survey. Vol. 3, Special Studies Part 1 of the 2017 Census of Agriculture, AC-17-SS-1. Washington, DC: USDA-NASS. Retrieved from https://www.nass.usda.gov/Publications/AgCensus/2017/Online _Resources/Farm_and_Ranch_Irrigation_Survey/fris.pdf 
USDA-NRCS. (2012a). 1971- 2000 average precipitation raster data set derived from data provided by PRISM Climate Group, Oregon State University, http://prism.oregonstate.edu published on the Geospatial Data Gateway. Washington, DC: USDANRCS. Retrieved from https://nrcs.app.box.com/v/gateway/folder/22222129604

USDA-NRCS. (2012b). PHAUCET version 8.2.0. Washington, DC: USDA-NRCS. Retrieved from

https://www.nrcs.usda.gov/wps/portal/nrcs/detailfull/national/nd csmc/?cid=stelprdb1042198

USDC. (1984). 1984 Farm and Ranch Irrigation Survey. AG84-SR1 Special Report Series. Prepared for the United States Department of Agriculture, Economic Research Service. Washington, DC: USDC, Bureau of the Census. Retrieved from http:/usda.mannlib.cornell.edu/usda/AgCensusImages/1982/03/ 4.pdf

USDC. (1990). Farm and Ranch Irrigation Survey (1988), AC87RS-1, 1987 Census of Agriculture, Volume 3, Part 1. Washington, DC: USDC, Bureau of the Census. Retrieved from http://usda.mannlib.cornell.edu/usda/AgCensusImages/1987/03/ 01/1987-03-01.pdf

Vellidis, G., Liakos, V., Andreis, J. H., Perry, C. D., Porter, W. M., Barnes, E. M.,... Migliaccio, K. W. (2016). Development and assessment of a smartphone application for irrigation scheduling in cotton. Comput. Electron. Agric., 127, 249-259. https://doi.org/10.1016/j.compag.2016.06.021

Vellidis, G., Tucker, M., Perry, C., Kvien, C., \& Bednarz, C. (2008). A real-time wireless smart sensor array for scheduling irrigation. Comput. Electron. Agric., 61(1), 44-50. https://doi.org/10.1016/j.compag.2007.05.009

Vories, E. D., Greene, J. K., Teague, T. G., Stewart, J. H., Phipps, B. J., Pringle, H. C.,... Griffin, T. W. (2011). Determining the optimum timing for the final furrow irrigation on Midsouth cotton. Appl. Eng. Agric., 27(5), 737-745. https://doi.org/10.13031/2013.39574

Vories, E. D., Hogan, R., Tacker, P. L., Glover, R. E., \& Lancaster, S. W. (2007). Estimating the impact of delaying irrigation for midsouth cotton on clay soil. Trans. ASABE, 50(3), 929-937. https://doi.org/10.13031/2013.23157

Walter, I. A., Allen, R. G., Elliott, R., Itenfisu, D., Brown, P., Jensen, M. E.,... Wright, J. L. (2005). The ASCE Standardized reference evapotranspiration equation. Reston, VA: ASCEEWRI.
Wanjura, D. F., Upchurch, D. R., \& Mahan, J. R. (1990). Evaluating decision criteria for irrigation scheduling of cotton. Trans. ASAE, 33(2), 512-518. https://doi.org/10.13031/2013.31359

Wanjura, D. F., Upchurch, D. R., \& Mahan, J. R. (1995). Control of irrigation scheduling using temperature-time thresholds. Trans. ASAE, 38(2), 403-409. https://doi.org/10.13031/2013.27846

Wanjura, D. F., Upchurch, D. R., \& Mahan, J. R. (2006). Behavior of temperature-based water stress indicators in BIOTICcontrolled irrigation. Irrig. Sci., 24(4), 223-232. https://doi.org/10.1007/s00271-005-0021-9

Wanjura, D. F., Upchurch, D. R., Hatfield, J. L., Burke, J. J., \& Mahan, J. R. (1988). Cotton irrigation using the" thermal kinetic window" criteria. Proc. Beltwide Cotton Production Research Conf., (pp. 183-185).

Wiegand, C. L., \& Namken, L. N. (1966). Influences of plant moisture stress, solar radiation, and air temperature on cotton leaf temperature. Agron. J., 58(6), 582-586. https://doi.org/10.2134/agronj1966.00021962005800060009x

Wiggins, M. S., Leib, B. G., Mueller, T. C., \& Main, C. L. (2013). Investigation of physiological growth, fiber quality, yield, and yield stability of upland cotton varieties in differing environments. J. Cotton Sci., 17(3), 140-148.

Wiggins, M. S., Leib, B. G., Mueller, T. C., \& Main, C. L. (2014). Cotton growth, yield, and fiber quality response to irrigation and water deficit in soil of varying depth to a sand layer. J. Cotton Sci., 18(2), 145-152.

Yaeger, M. A., Reba, M. L., Massey, J. H., \& Adviento-Borbe, M. A. A. (2017). On-farm irrigation reservoirs in two Arkansas critical groundwater regions: A comparative inventory. Appl. Eng. Agric., 33(6), 869-878. https://doi.org/10.13031/aea.12352

Yoder, R. E., Johnson, D. L., Wilkerson, J. B., \& Yoder, D. C. (1998). Soilwater sensor performance. Appl. Eng. Agric., 14(2), 121-133. https://doi.org/10.13031/2013.19373

Zhou, X. V., Boyer, C., Larson, J. A., Leib, B., \& Gwathmey, O. (2016). Profit-maximizing irrigation for cotton on high available water holding capacity soils. Agron. J., 108(4), 1571-1580. https://doi.org/10.2134/agronj2015.0602

Zwart, S. J., \& Bastiaanssen, W. G. M. (2004). Review of measured crop water productivity values for irrigated wheat, rice, cotton and maize. Agric. Water Manag., 69(2), 115-133. https://doi.org/10.1016/j.agwat.2004.04.007 